\title{
Diversifikasi korporasi dan biaya modal
}

\author{
Katiya Nahda ${ }^{1}$, Marwan Asri ${ }^{2}$ \\ ${ }^{1}$ Universitas Islam Indonesia, Yogyakarta, Indonesia \\ Corresponding author Email: katiya.nahda@uii.ac.id \\ ${ }^{2}$ Universitas Gadjah Mada, Yogyakarta, Indonesia \\ Email: marwan@mm.ugm.ac.id
}

\begin{abstract}
This paper studies the relation between corporate diversification and cost of capital. It examines whether cost of capital is affected by an organizational form under various levels of financial constraints and cash flow correlations. The sample was taken across non-financial sectors listed on the Indonesian Stock Exchange (IDX) over the period 2010-2014. Feasible Generalized Least Square (FGLS) is used to test the hypotheses. The findings show that a firm's cost of capital is positively affected by the level of corporate diversification. However, the result of a separate regression shows a dual effect of corporate diversification on cost of debt and cost of equity. Another key finding, lower cash flow correlations between business segments, corresponds to lower cost of capital, which supports the co-insurance hypothesis. The less correlated the cash flows, the greater the co-insurance effect would be generated, reducing a firm's cost of capital. In addition, when the sample is divided between financially and non-financially constrained firms, the results show a significant effect only in financially constrained firms. It indicates that the influence of diversification on firm's cost of capital is more pronounced for financially constrained firms.
\end{abstract}

Keywords: cash flow correlation, corporate diversification, cost of capital, financial constraint.

\begin{abstract}
Abstrak
Tujuan penelitian ini adalah menguji pengaruh diversifikasi usaha terhadap biaya modal dikaitkan dengan korelasi arus kas antar segmen serta tingkat kendala pendanaan yang dihadapi perusahaan. Model penelitian diuji dengan menggunakan sampel dari seluruh perusahaan di luar sektor keuangan yang terdaftar di Bursa Efek Indonesia periode 2010-2014 dengan metode Feasible Generalized Least Square (FGLS). Hasil penelitian menunjukkan diversifikasi usaha berpengaruh positif terhadap biaya modal secara keseluruhan. Namun, pengujian model secara parsial menunjukkan adanya perbedaan pengaruh diversifikasi terhadap biaya utang dan biaya ekuitas. Di satu sisi diversifikasi usaha menurunkan biaya utang, di sisi lain juga dapat meningkatkan biaya ekuitas. Temuan lain menunjukkan semakin rendah korelasi arus kas antar segmen usaha, semakin rendah biaya modal yang ditanggung perusahaan. Tingkat kendala pendanaan juga menunjukkan pengaruh signifikan dalam memoderasi hubungan diversifikasi usaha dengan biaya modal.
\end{abstract}

Kata kunci: biaya modal, diversifikasi usaha, kendala pendanaan,korelasi arus kas.

$\begin{array}{ll}\text { JEL:G320 DOI: 10.20885/jsb.vol21.iss2.art6 } & \text { D }\end{array}$

\section{Pendahuluan}

Isu terkait diversifikasi usaha sudah banyak diteliti, diawali oleh Wernerfelt dan Montgomery (1988). Sebagian besar penelitian sebelumnya fokus pada pengaruh diversifikasi usaha terhadap nilai perusahaan dengan berbagai kontradiksi hasil (Berger \& Ofek, 1995; Campa \& Kedia, 2002; Graham, Lemmon, \& Wolf, 2002; Lang \& Stulz, 1994; Mansi \&Reeb, 2002; Villalonga, 2004). Oweis (2012) mengklasifikasikan berbagai penelitian tersebut ke dalam empat gelombang. Gelombang pertama menemukan diversifikasi usaha menurunkan nilai perusahaan (Berger \& Ofek, 1995; Lang \& Stulz, 1994; Wernerfelt \& Montgomery 1988). Gelombang kedua menjelaskan pengaruh negatif diversifikasi usaha terhadap nilai perusahaan dikarenakan perilaku rent-seeking dari manajer, serta adanya inefisiensi dalam alokasi sumber daya internal (Denis, Denis, \& Sarin, 1997; May, 1995; 
Scharfstein, 1999). Gelombang ketiga mulai muncul pertentangan. Sebagian peneliti menemukan diversifikasi usaha tidak mengurangi nilai perusahaan. Penurunan nilai yang terjadi lebih disebabkan oleh perbedaan karakteristik perusahaan, seperti ukuran, laba operasi, dan tingkat pertumbuhan (Campa \& Kedia, 2002), likuiditas dan gaji eksekutif (Hyland \& Diltz, 2002), serta kinerja perusahaan sebelum melakukan diversifikasi (Graham, Lemon, \& Wolf, 2002). Temuan ini diperkuat oleh kelompok terakhir. Menurut mereka pengaruh negatif diversifikasi usaha terhadap nilai perusahaan tidak pernah benar-benar terjadi. Berbagai temuan negatif sebelumnya lebih disebabkan oleh pemilihan sampel yang bias, serta penggunaan instrumen pengukuran dan teknik ekonometrika yang kurang tepat (Mansi \& Reeb, 2002; Schoar, 2002).

Penelitian ini melengkapi berbagai literatur sebelumnya dengan menganalisa dampak diversifikasi usaha terhadap biaya modal yang jumlahnya masih sangat terbatas. Menurut Hann, Ogneva, dan Ozbas (2013) hal ini dikarenakan adanya pandangan yang berkembang di berbagai penelitian sebelumnya bahwa bentuk perusahaan apakah itu bersifat segmen tunggal (tidak terdiversifikasi) atau multi-segmen (terdiversifikasi) tidak berpengaruh terhadap biaya modal. Lebih jauh Hann et. al. (2013) mengungkapkan berkembangnya pandangan tersebut disebabkan peneliti sebelumnya menggunakan konsep merger dalam menjelaskan pengaruh diversifikasi usaha terhadap risiko perusahaan, sebagaimana dilakukan oleh Higgins dan Schall (1975), Kim dan McConnell (1977), Ross, Westerfield, dan Jaffe, (2008), Schall (1972), serta Scott (1977). Berdasarkan perspektif merger perusahaan terdiversifikasi tetap dipandang sebagai entitas tunggal, sehingga kegiatan subsidi silang dan mekanisme pendanaan internal tidak bisa dilakukan. Dengan demikian, korelasi arus kas yang tidak sempurna antar unit bisnis dianggap hanya mampu mengurangi risiko idiosyncratic, sedangkan risiko sistematisnya tetap sama.

Dengan menggunakan pandangan berbeda, Hann et. al. (2013) menemukan perusahaan terdiversifikasi memiliki biaya modal lebih rendah dibanding perusahaan tidak terdiversifikasi. Risiko sistematis perusahaan terdiversifikasi dapat dikurangi melalui mekanisme co-insurance yang diperkenalkan oleh Lewellen (1971). Korelasi arus kas yang tidak sempurna antar unit bisnis dapat menurunkan variabilitas arus kas sehingga menurunkan risiko kebangkrutan melalui perataan laba (income smoothing). Dalam perspektif co-insurance setiap unit bisnis dipandang sebagai perusahaan dengan segmen tunggal, sehingga perusahaan terdiversifikasi merupakan kumpulan berbagai perusahaan dengan segmen tunggal. Ketika perusahaan memiliki beberapa unit bisnis, maka risiko akan tersebar ke berbagai unit bisnis. Pada kondisi krisis perusahaan terdiversifikasi memiliki kesempatan untuk melakukan subsidi silang dari unit bisnis yang surplus dana ke unit bisnis yang mengalami defisit, sehingga mengurangi probabilitas kebangkrutan. Pengurangan risiko perusahaan akan mengurangi biaya modal karena tingkat keuntungan yang disyaratkan investor berkorelasi positif dengan risiko.

Galai dan Masulis (1976), Higgins dan Schall (1975), serta Mansi dan Reeb (2002) yang juga menggunakan konsep co-insurance menemukan adanya pengaruh ganda dari diversifikasi usaha terhadap biaya modal. Di satu sisi penurunan risiko perusahaan akibat diversifikasi akan meningkatkan kapasitas utang dan atau mengurangi biaya utang, namun di sisi lain peningkatan utang akan meningkatkan risiko pemegang saham sehingga tingkat keuntungan yang disyaratkan akan meningkat. Dengan adanya pengaruh ganda tersebut, penelitian ini bertujuan untuk menguji dampak akhirdari pengaruh tersebut secara keseluruhan.

Selain itu hasil penelitian Franco, Urcan, dan Vasvari (2010), Hann et. al. (2013), serta Leland (2007) menunjukkan kemampuan diversifikasi usaha dalam mengurangi risiko akan semakin besar ketika tingkat korelasi arus kas antar unit bisnis rendah. Dengan kata lain, tingkat korelasi arus kas mempengaruhi risiko sistematis. Perusahaan yang memiliki korelasi arus kas yang rendah antar unit bisnis memiliki kesempatan lebih besar untuk melakukan transfer sumber daya dari unit bisnis yang surplus ke unit bisnis yang mengalami defisit, sehingga manfaat co-insurance yang dihasilkan semakin besar. Hasil penelitian Matsusaka dan Nanda (2002), Stein (1997), serta Yan (2006) menunjukkan nilai perusahaan terdiversifikasi juga meningkat ketika perusahaan mengalami 
kendala pendanaan tinggi. Hal ini dikarenakan pada kondisi tersebut biaya pendanaan dari sumber eksternal sangat tinggi, sehingga manfaat sumber pendanaan internal melalui diversifikasi usaha akan semakin besar.

Penelitian ini fokus pada pengujian pengaruh diversifikasi usaha terhadap biaya modal, dikaitkan dengan tingkat korelasi arus kas antar segmen usaha, serta kendala pendanaan. Ada tiga alasan utama yang mendasari penelitian ini. Pertama, menjawab pertanyaan mengapa perusahaan tetap melakukan diversifikasi usaha meskipun banyak hasil penelitian menunjukkan adanya pengaruh negatif terhadap nilai perusahaan. Dalam upaya menjawab pertanyaan tersebut, keputusan diversifikasi kemudian dikaitkan dengan risiko dan biaya modal perusahaan. Hal ini diperkuat dengan berkembangnya fenomena konglomerasi di Indonesia yang ditandai dengan banyaknya korporasi bisnis yang menguasai berbagai sektor usaha. Alasan kedua mengapa penelitian ini relevan dilakukan, dikarenakan berbagai penelitian sebelumnya lebih banyak menyoroti isu kinerja. Hann et. al. (2013) menyebutkan penelitian mereka merupakan penelitian pertama yang menguji pengaruh diversifikasi usaha terhadap biaya modal dengan perspektif $\mathrm{CO}$ insurance. Alasan ketiga, Penelitian serupa masih jarang dilakukan dalam konteks negara berkembang, khususnya Indonesia. Padahal isu ini menjadi fenomena menarik untuk diteliti di negara tersebut. Kondisi pasar modal yang belum mapan, serta masih lemahnya regulasi terkait perlindungan investor menyebabkan mekanisme pendanaan internal menjadi sumber pendanaan dominan.

\section{Reviu Literatur dan Pengembangan Hipotesis}

\section{Diversifikasi Usaha dan Biaya Modal}

Ada dua mekanisme yang menjelaskan pengaruh diversifikasi usaha terhadap risiko perusahaan sehingga mengurangi biaya modal, yaitu melalui peningkatan kapasitas utang (Berger \& Ofek, 1995; Franco, Urcan \& Vasvari, 2010, Kuppuswamy \& Villalonga, 2010) dan pemanfaatan sumber dana internal (Matsusaka \& Nanda, 2002; Stein, 1997; Stulz, 1990). Peningkatan kapasitas utang dapat dilakukan karena perusahaan terdiversifikasi memiliki risiko lebih rendah akibat co-insurance effect (Lewellen, 1971). Kuppuswamy dan Villalonga (2010) menemukan risiko perusahaan terdiversifikasi lebih rendah dibanding perusahaan tidak terdiversifikasi ditunjukkan oleh peringkat obligasi yang lebih baik, sehingga memiliki kesempatan lebih besar untuk mengakses sumber dana eksternal dengan biaya lebih rendah. Pada kondisi normal, perusahaan akan merealisasikan kesempatan untuk meningkatkan utang agar mendapatkan manfaat pajak (Jahera \& Lloyd, 1996; Kraus \& litzenberger, 1973), serta meningkatkan efisiensi operasional dengan monitoring yang lebih baik (Jensen, 1986; Jensen \& Meckling, 1976). Kim \& McConnel (1977) menemukan perusahaan dengan volatilitas laba yang relatif stabil memiliki kapasitas utang lebih tinggi. Hasil selaras ditunjukkan Shleifer dan Vishny (1992), perusahaan terdiversifikasi memiliki kapasitas utang lebih tinggi dibanding perusahaan tidak terdiversifikasi walaupun pada tingkat volatilitas arus kas yang sama.

Mekanisme kedua menjelaskan bahwa perusahaan terdiversifikasi bisa mendapatkan sumber pendanaan internal dengan biaya lebih murah pada saat krisis, melalui transfer sumber daya dari unit bisnis yang kelebihan dana ke unit bisnis yang kekurangan dana (Matsusaka \& Nanda, 2002; Stein, 1997). Asumsi utama penelitian ini, diversifikasi usaha hanya berpengaruh terhadap biaya modal jika terjadi perubahan leverage. Sebagaimana dijelaskan oleh co-insurance effect, penurunan risiko perusahaan akan menurunkan biaya utang dan atau meningkatkan kapasitas utang. Di sisi lain, peningkatan leverage akan meningkatkan biaya kebangkrutan yang akan meningkatkan biaya ekuitas (Stulz, 1990). Penelitian ini meyakini penurunan nilai ekuitas dapat dikompensasi dengan peningkatan manfaat pajak yang diterima akibat penambahan utang. Oleh karena itu, hipotesis pertama diformulasikan sebagai berikut:

$\mathrm{H}_{1}$ : Diversifikasi usaha akan menurunkan biaya modal perusahaan. 


\section{Diversifikasi Usaha, Korelasi Arus Kas, dan Biaya Modal}

Sebagaimana dijelaskan sebelumnya, diversifikasi usaha dapat mengurangi biaya modal melalui peningkatan kapasitas utang (Berger \& Ofek, 1995; Franco et. al. 2010; Kuppuswamy \& Villalonga, 2010; Lewellen, 1971). Seberapa besar peningkatan kapasitas utang ditentukan oleh kemampuan diversifikasi dalam menurunkan risiko sistematis, melalui pengurangan volatilitas arus kas (Franco et. al., 2010). Dengan kata lain, korelasi arus kas merupakan salah satu komponen yang mempengaruhi risiko sistematis. Perusahaan yang menerapkan strategi diversifikasi tidak terkait memiliki korelasi arus kas lebih rendah antar unit bisnisnya dibanding diversifikasi terkait, sehingga memiliki kesempatan lebih besar untuk melakukan subsidi silang. Semakin rendah korelasi arus kas, risiko sistematis yang bisa dikurangi juga semakin tinggi, sehingga manfaat co-insurance semakin besar (Leland, 2007; Hann, Ogneva, \& Ozbas 2013). Hasil penelitian Barton dan Gordon (1988) menunjukkan perusahaan yang melakukan diversifikasi tidak terkait memiliki proporsi utang lebih tinggi dibanding perusahaan yang melakukan diversifikasi terkait.

Pengaruh korelasi arus kas terhadap pengurangan risiko juga bisa dijelaskan dengan konsep pendanaan internal. Hasil penelitian Duchin (2010), Kuppuswamy dan Villalonga (2010), serta Rajan, Servaes, dan Zingales (2000) menunjukkan semakin rendah tingkat keterkaitan usaha, semakin besar manfaat co-insurance. Hal ini dikarenakan kemungkinan kesempatan investasi terjadi secara bersamaan semakin rendah. Ketika peluang investasi tidak tersedia secara simultan pada waktu yang sama, maka kemungkinan perusahaan mendapatkan sumber pendanaan internal semakin besar. Dengan demikian kemampuan diversifikasi usaha dalam mengurangi probabilitas kebangkrutan akan semakin tinggi. Hal ini mengindikasikan jika arus kas antar unit bisnis memiliki korelasi sempurna, maka risiko sistematis yang dihadapi perusahaan terdiversifikasi akan sama dengan perusahaan tidak terdiversifikasi, sehingga biaya modalnya juga akan sama.Oleh karena itu hipotesis kedua dirumuskan sebagai berikut:

$\mathrm{H}_{2}$ : Semakin tinggi tingkat korelasi arus kas antar unit bisnis, semakin lemah pengaruh diversifikasi usaha terhadap pengurangan biaya modal perusahaan.

\section{Diversifikasi Usaha, Kendala Pendanaan, dan Biaya Modal}

Sama halnya dengan korelasi arus kas, pengaruh kendala pendanaan terhadap diversifikasi usaha dan biaya modal juga dijelaskan oleh dua mekanisme. Pertama, perusahaan terdiversifikasi memiliki kapasitas utang lebih tinggi dan atau biaya utang lebih rendah akibat co-insurance effect (Berger \& Ofek, 1995; Franco et. al., 2010; Kuppuswamy \& Villalonga, 2010; Lewellen, 1971). Pada tingkat kendala pendanaan yang sama, perusahaan terdiversifikasi dengan risiko lebih rendah, memiliki probabilitas lebih besar untuk mendapatkan sumber pendanaan eksternal dengan biaya lebih murah dibanding perusahaan tidak terdiversifikasi (Yan, 2006).

Mekanisme kedua berkaitan dengan sumber pendanaan internal. Perusahaan dengan tingkat kendala pendanaan tinggi, sangat bergantung pada sumber internal untuk menghindari tingginya biaya pendanaan eksternal (Matsusaka \& Nanda, 2002; Stein, 1997). Perusahaan terdiversifikasi memiliki akses lebih besar terhadap sumber internal yang dapat mengurangi biaya modal (Hoshi, Kashyap, \& Scharfstein, 1991; Leland, 2007). Menurut Shin dan Stulz (1998) dengan adanya subsidi silang sumber daya, perusahaan terdiversifikasi dimungkinkan untuk merealisasikan kesempatan investasi dari berbagai unit bisnis walaupun unit bisnis tersebut mengalami kendala pendanaan.

Hann et. al. (2013) menemukan manfaat co-insurance dari diversifikasi usaha akan semakin besar ketika perusahaan menghadapi kendala pendanaan tinggi. Hal ini dikarenakan perusahaan dengan tingkat kendala pendanaan tinggi memiliki kemungkinan lebih besar terjadinya financial distress. Hasil selaras ditunjukkanStein (1997), sumber pendanaan internal memberikan manfaat lebih besar bagi perusahaan dengan kendala pendanaan tinggi. Kuppuswamy dan Villalonga (2010) yang meneliti terkait diversifikasi usaha, kendala pendanaan, dan nilai perusahaan menemukan hasil konsisten dengan 3 temuan utama. Pertama, pengaruh diversifikasi usaha terhadap nilai perusahaan akan semakin kuat ketika terjadi krisis. Hal ini dikarenakan meningkatnya kendala pendanaan pada 
saat krisis, sehingga manfaat sumber dana internal semakin besar. Kedua, kegiatan alokasi sumber dana internal semakin efisien pada saat krisis, karena tingginya biaya modal eksternal. Terakhir, debtholders lebih memilih berinvestasi pada perusahaan terdiversifikasi dibanding perusahaan tidak terdiversifikasi pada saat krisis. Oleh karena itu, hipotesis ketiga dirumuskan sebagai berikut:

$\mathrm{H}_{3}$ : Semakin tinggi kendala pendanaan yang dihadapi perusahaan, semakin kuat pengaruh diversifikasi usaha terhadap pengurangan biaya modal.

Berdasarkan 3 hipotesis di atas, rerangka penelitian digambarkan sebagai berikut:

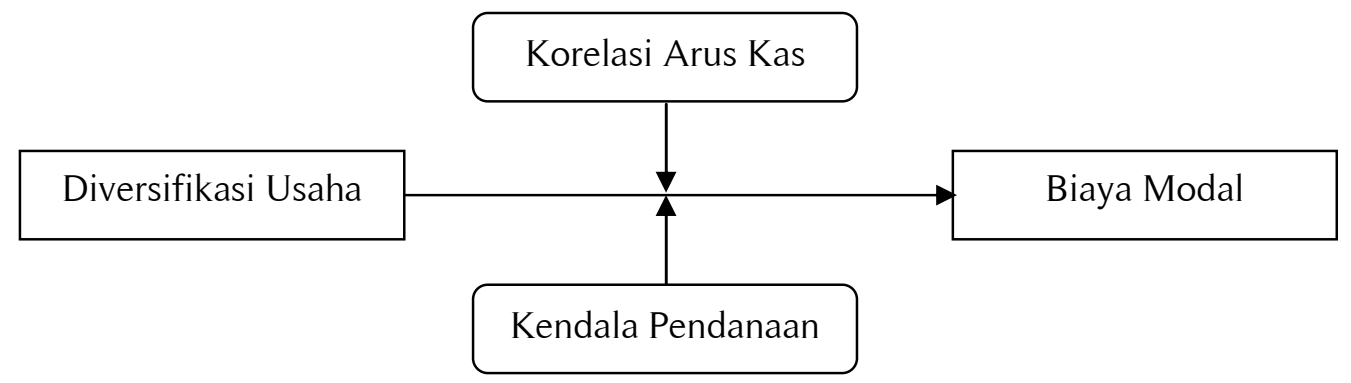

Gambar 1. Rerangka Penelitian

\section{Metode Penelitian}

\section{Data dan Sampel}

Sampel penelitian adalah seluruh perusahaan non-keuangan yang terdaftar di Bursa Efek Indonesia (BEI) periode 2008-2014. Sektor keuangan dikeluarkan dari sampel dikarenakan masuk dalam kategori highly regulated, sehingga memiliki karakteristik berbeda, khususnya terkait pendanaan. Pada dasarnya data yang digunakan untuk pengujian hipotesis hanya 2010-2014, namun data dua periode sebelumnya (2008-2009) diperlukan untuk mengestimasi nilai korelasi arus kas dan biaya ekuitas pada periode t. Data bersifat panel dan diambil dari website BEI, Kustodian Sentral Efek Indonesia (KSEI), OSIRIS, dan Yahoo finance. Metode purposive sampling digunakan dalam pengumpulan sampel, dengan kriteria sebagai berikut: a) Perusahaan tidak bergerak di industri keuangan, dan tidak memiliki unit bisnis yang bergerak di industri tersebut. b) Memiliki lebih dari 2 segmen usaha secara konsisten selama periode pengamatan, dan adanya kontinuitas usaha segmen minimal 3 tahun berturut-turut. c) Perusahaan mengungkapkan informasi penjualan, laba usaha, depresiasi, dan amortisasi dari tiap segmen di dalam laporan keuangan tahunan.

\section{Definisi Operasional dan Pengukuran Variabel}

\section{Biaya modal}

Biaya modal dihitung dengan formula WACC (weighted average cost of capital) yang merupakan hasil penjumlahan dari rata-rata tertimbang biaya utang dan biaya ekuitas (Ehrhardt \& Brigham, 2011) (Persamaan 1, 2, dan 3). Biaya utang merupakan rata-rata tertimbang dari biaya utang bank dan biaya obligasi. Biaya utang bank dihitung sebesar tingkat bunga utang jangka panjang setelah dikurangi pajak (Persamaan 4). Biaya utang obligasi dihitung sebesar yield to maturity (YTM) (Persamaan 5). Sedangkan biaya ekuitas dihitung dengan capital asset pricing model (CAPM) (Persamaan 6). Sebagaimana diketahui, tidak semua perusahaan di Indonesia menerbitkan obligasi, maka peneliti menggunakan pengukuran biaya utang alternatif yang dihitung dari total beban bunga yang dikeluarkan perusahaan dibandingkan dengan total utang jangka panjang (Persamaan 7).

$W A C(=$ weighted average COD + weighted average COE

Weighted average COD $=\frac{\text { Nilai pasar utang }}{\text { Nilai pasar utang }+ \text { Nilai pasar ekuitas }} x(\mathrm{COD})$ 
Weighted average $C O E=\frac{\text { Nilai pasar ekuitas }}{\text { Nilai pasar utang+Nilai pasar ekuitas }} x(\mathrm{COE})$

Cost of Bank's Debt = Interest rate - tax savings

$V b=\sum_{n=1}^{N}\left(\frac{\mathrm{INT}}{\left(1+\mathrm{YTN}_{2}\right)^{\mathrm{t}}}+\frac{\mathrm{M}}{\left(1+\mathrm{YTN}_{2}\right)^{\mathrm{n}}}\right)$

$\mathrm{E}(\mathrm{R})_{\mathrm{i}, \mathrm{t}}=R_{f t}+\beta\left(R_{m t}-R_{f t}\right)$

CostofDebt $=\frac{\text { Total interest expense }}{\text { Total long-term debt }} x(1-$ tax $)$

Keterangan;

$\mathrm{COD}=$ Cost of debt (biaya utang)

$\mathrm{COE}=$ Cost of equity (biaya ekuitas)

$\mathrm{Vb} \quad=$ Harga obligasi

INT = Tingkat bunga/coupon rate

$\mathrm{M} \quad=$ Nilai nominal

$\mathrm{E}(\mathrm{R}) \quad=$ Expected return (biaya ekuitas)

$\mathrm{Rf} \quad=$ Risk free rate (tingkat keuntungan bebas risiko yang diukur dengan tingkat bunga obligasi pemerintah dengan maturity rata-rata 10 tahun.

$\mathrm{Rm} \quad=$ Tingkat keuntungan pasar yang diperoleh dari return IHSG

$\beta=$ Beta atau risiko sistematis yang diukur dengan sensitivitas perubahan return saham terhadap pergerakan return pasar berdasarkan model regresi.

\section{Diversifikasi usaha}

Diversifikasi usaha diukur dengan 2 cara, yaitu berdasarkan jumlah segmen usaha dan indeks Herfindahl (Berger \& Ofek, 1995; Denis et. al., 1997; Franco et. al., 2010; Mansi \& Reeb, 2002). Indeks Herfindahl dihitung dari jumlah kuadrat penjualan masing-masing segmen dibagi dengan kuadrat total penjualan perusahaan (Persamaan 8).

$H I=\sum_{n=1}^{N}\left(\frac{\text { segsales }}{\text { total sales }}\right)^{2}$

\section{Korelasi arus kas dan kendala pendanaan}

Korelasi arus kas diukur dengan pearson correlation dari EBITDA (earnings beforeinterest, taxes, depreciation, and amortization) (Franco et. al., 2010; Kini \& Williams, 2012). Kendala pendanaan diukur dengan 3 cara, yaitu peringkat obligasi, rasio keuangan, serta rasio pembayaran dividen. Berdasarkan data BEI 2010-2014, jumlah perusahaan yang menerbitkan obligasi sangat terbatas. Oleh karena itu, peneliti menggunakan metode alternatif untuk klasifikasi kendala pendanaan dengan rasio keuangan. Ada 5 rasio utama yang menentukan peringkat obligasi, yaitu coverage, leverage, likuiditas, profitabilitas, dan cash flow-to-debt-ratio (Bodie, Kane \& Marcus, 2011). Penelitian ini menggunakan 2 rasio sebagai alternatif peringkat obligasi, yaitu coverage ratio dan rasio likuiditas untuk menghindari terjadinya korelasi yang tinggi dengan variabel kontrol. Coverage ratio diukur dengan times interest earned (TIE)dan rasio likuiditas diukur dengan current ratio. Metode ketiga, kendala pendanaan diukur berdasarkan rasio pembayaran dividen (Kuppuswamy \& Villalonga, 2010).

\section{Variabel kontrol}

Ada 4 variabel kontrol yang digunakan mengacu pada Franco et. al. (2010), Hannet. al. (2013), serta Kuppuswamy dan Villalonga (2010), yaitu leverage, kinerja perusahaan, ukuran perusahaan, dan market-to-book ratio. Leverage dihitung dengan formula Hannet. al. (2013) (9).

Leverage $=\frac{\text { Nilai buku utang jangka panjang }}{\text { Nilai buku utang jangka panjang+Nilai pasar ekuitas }}$ 
Kinerja perusahaan diukur dengan return on assets (ROA), untuk mengontrol kemampuan perusahaan dalam menghasilkan laba. Semakin tinggi profitabilitas maka semakin rendah probabilitas kebangkrutan. Ukuran perusahaan diukur dengan logarithm natural dari total aset perusahaan. Market-to-book ratio yang merepresentasikan kesempatan perusahaan untuk tumbuh dijadikan indikator risiko perusahaan.

\section{Teknik analisis data}

Selanjutnya dikembangkan model pengujian hipotesis untuk regresi panel yang dilakukan secara bertahap. Model I untuk pengujian hipotesis pertama (Persamaan 10), model II untuk pengujian hipotesis kedua (Persamaan 11), model III untuk pengujian hipotesis ketiga (Persamaan 12), dan model IV untuk pengujian secara menyeluruh (Persamaan 13).

Model I

$\mathrm{COC}_{i \mathrm{t}}=\beta_{1}-\beta_{2} \mathrm{DIVER}_{\mathrm{it}}+\beta_{3} \mathrm{LEV}_{\mathrm{it}}-\beta_{4} \mathrm{ROA}_{\mathrm{it}}+\beta_{5} \mathrm{SIZE}_{\mathrm{it}}+\beta_{6} \mathrm{MB}_{\mathrm{it}}+\varepsilon_{\mathrm{it}}$

Model II

$\mathrm{COC}_{i \mathrm{t}}=\beta_{1}-\beta_{2} \mathrm{DIVER}_{\mathrm{it}}+\beta_{3} \mathrm{CFC}_{\text {it }}+\beta_{5} \mathrm{LEV}_{\mathrm{it}}-\beta_{6} \mathrm{ROA}_{\mathrm{it}}+\beta_{7} \mathrm{SIZE}_{\mathrm{it}}+\beta_{8} \mathrm{MB}_{\mathrm{it}}+\varepsilon_{\mathrm{it}}$

Model III

$\mathrm{COC}_{\mathrm{it}}=\beta_{1}-\beta_{2} \mathrm{DIVER}_{\mathrm{it}}+\beta_{3} \mathrm{FCON}_{\mathrm{it}}+\beta_{5} \mathrm{LEV}_{\mathrm{it}}-\beta_{6} \mathrm{ROA}_{\mathrm{it}}+\beta_{7} \mathrm{SIZE}_{\mathrm{it}}+\beta_{8} \mathrm{MB}_{\mathrm{it}}+\varepsilon_{\mathrm{it}}$

Model IV

$$
\begin{aligned}
\text { COC }_{i t}= & \beta_{1}-\beta_{2} \text { DIVER }_{i t}+\beta_{3} \text { CFC }_{i t}+\beta_{4} \text { FCON }_{i t}-\beta_{5}(C F C * \text { DIVER })_{i t}+\beta_{6}\left(\text { FCON }^{*} \text { DIVER }\right)_{i t} \\
& +\beta_{7} \text { LEV }_{\text {it }}-\beta_{8} \text { ROA }_{i t}+\beta_{9} \text { SIZE }_{i t}+\beta_{10} M_{i t}+\varepsilon_{i t}
\end{aligned}
$$

Keterangan:

COC : Cost of capital (biaya modal)

DIVER : Tingkat diversifikasi usaha

CFC : Cash flow correlation (tingkat korelasi arus kas antar unit bisnis)

FCON : Financial constraints (kendala pendanaan)

LEV : Leverage

ROA : Return on assets (kinerja perusahaan)

SIZE : Ukuran perusahaan

MB : Market-to-book ratio

Hasil pengujian asumsi klasik, menunjukkan adanya permasalahan terkait normalitas data dan autokorelasi. Karena asumsi normalitas pada data panel memang sulit dicapai, peneliti fokus pada masalah autokorelasi. Menurut Gujarati dan Porter (2011) estimasi dalam kondisi autokorelasi dapat memberikan hasil yang bias dikarenakan varians dari beta estimator menjadi terlalu besar. Hal ini menyebabkan interval kepercayaan menjadi lebih tinggi, atau dengan kata lain nilai t-statistik menjadi lebih kecil dari seharusnya, sehingga secara statistik terlihat tidak signifikan, yang mengarah pada penarikan kesimpulan yang salah. Oleh sebab itu model penelitian ini diuji dengan menggunakan FGLS (Feasible Generalized Least Square) dengan pendekatan fixed effect berdasarkan hasil pengujian chow-test dan hausman-test. Pengaruh moderasi diuji dengan metode pemisahan sampel berdasarkan kategori perusahaan yang memiliki korelasi arus kas tinggi, korelasi arus kas rendah, kendala pendanaan tinggi, dan kendala pendanaan rendah dengan median sebagai nilai cut-off. Kemudian hipotesis diuji pada masing-masing sub-sampel, sehingga terdapat empat hasil pengujian. 


\section{Hasil Penelitian Dan Pembahasan}

\section{Statistik Deskriptif}

Hasil statistik deskriptif yang disajikan pada tabel 1 menunjukkan rata-rata biaya modal perusahaan terdiversifikasi $11,5 \%$. Jika dilihat selisih biaya modal terendah dengan tertinggi, menunjukkan tingkat variasi yang masih tinggi 30,8\%. Variabel diversifikasi usaha menunjukkan rata-rata perusahaan memiliki 4 segmen usaha. Hanya 3 perusahaan yang memiliki lebih dari 6 segmen, yaitu PT Intiland Development (7 segmen), PT Japfa Comfeed Indonesia (8 segmen), dan PT Indofood Sukses Makmur (9 segmen). Hasil selaras ditunjukkan oleh nilai indeks herfindahl yang telah dikurangi 1. Rata-rata indeks yang rendah $(<0,5)$ mengindikasikan tingkat diversifikasi yang rendah. Nilai indeks herfindahl dari kelompok P75 sekalipun yang merupakan nilai rata-rata kategori $25 \%$ tertinggi masih tergolong diversifikasi moderat $(<0,8)$. Selisih nilai indeks tertinggi dengan nilai terendah juga sangat tinggi $(0,795)$. Hal ini dikarenakan ada beberapa perusahaan yang walaupun memiliki lebih dari 2 segmen usaha, namun penjualannya 90\% lebih masih dihasilkan oleh segmen utama, seperti PT Perusahaan Gas Negara (Persero), PT Berlian Laju Tanker, dan PT Barito Pacific.

Variabel korelasi arus kas menunjukkan tingkat korelasi arus kas antar segmen usaha yang cukup tinggi $(0,815)$. Hal ini mengindikasikan secara rata-rata kegiatan diversifikasi masih bergerak di bidang usaha dengan tingkat keterkaitan yang tinggi. Jika dilihat dari nilai P75, 25\% dari total observasi memiliki korelasi arus kas yang bahkan mendekati 1. Variabel kendala pendanaan menunjukkan hanya $32 \%$ dari sampel yang melakukan pembayaran dividen. Artinya $68 \%$ dari total observasi merupakan perusahaan yang mengalami kendala pendanaan. Jika mengacu pada rasio likuiditas dancoverage ratio, secara rata-rata perusahaan sampel tidak mengalami kendala pendanaan, dengan menggunakan nilai 1 sebagai cut-off. Nilai 1 dijadikan cut-off karena pada nilai tersebut perusahaan dianggap mampu melunasi seluruh beban tetap dan liabilitas jangka pendek yang dimilikinya. Variabel leverage menunjukkan nilai rata-rata 0,36 mengindikasikan proporsi utang di dalam perusahaan masih tergolong rendah dibanding ekuitas. Jika dilihat dari nilai minimum leverage, ada perusahaan yang struktur modalnya sepenuhnya (100\%) terdiri dari ekuitas.

Tabel 1. Statistik Deskriptif

\begin{tabular}{lrrrrrrr}
\hline Variabel & Mean & SD & MIN & MAX & P25 & P50 & P75 \\
\hline Pengukuran diversifikasi & & & & & & & \\
Jumlah Segmen & 3,923 & 1,085 & 3 & 9 & 3 & 3,661 & 5,21 \\
1-Ind. Herfindahl & 0,453 & 0,167 & 0,012 & 0,807 & 0,229 & 0,466 & 0,652 \\
Kendala pendanaan & & & & & & & \\
Div. paid dummy & 0,675 & 0,469 & 0 & 1 & 0 & 0,0848 & 1 \\
Current ratio & 1,99 & 2,153 & 0,145 & 22,015 & 0,794 & 1,519 & 4,136 \\
Times interest & 15,3 & 83,663 & $-6,452$ & 1124,33 & $-0,046$ & 4,224 & 57,5 \\
Kor. arus kas & 0,815 & 0,094 & 0,537 & 0,99 & 0,554 & 0,795 & 0,941 \\
Karakteristik perusahaan & & & & & & & \\
Leverage & 0,36 & 0,251 & 0 & 0,935 & 0,067 & 0,304 & 0,702 \\
Return on assets & 0,038 & 0,111 & $-0,654$ & 0,316 & $-0,063$ & 0,041 & 0,143 \\
Size (Ln tot. aset) & 29,353 & 1,442 & 25,716 & 32,579 & 27,262 & 29,379 & 31,047 \\
Market-to-book & 1,765 & 1,958 & $-0,581$ & 19,573 & 0,344 & 1,262 & 4,207 \\
Biaya Modal & & & & & & & \\
WACC 1 & 0,116 & 0,041 & 0,042 & 0,35 & 0,068 & 0,114 & 0,165 \\
WACC 2 & 0,115 & 0,041 & 0,04 & 0,35 & 0,071 & 0,113 & 0,162 \\
WACC 3 & 0,114 & 0,038 & 0,047 & 0,329 & 0,067 & 0,112 & 0,164 \\
WACC 4 & 0,114 & 0,038 & 0,04 & 0,329 & 0,071 & 0,111 & 0,16 \\
\hline Sumber : Hasil ol
\end{tabular}

Sumber : Hasil olah data 
Tabel 1 menyajikan statistik deskriptif variabel penelitian. Indeks herfindahl merupakan hasil kuadrat dari akumulasi penjualan tiap segmen dibagi penjualan total dikurangi 1. WACC merupakan weighted average biaya utang dan biaya ekuitas. Biaya ekuitas dihitung dengan CAPM. Biaya utang dihitung dengan (1) total beban bunga dibagi total utang jangka panjang, dan (2) weighted average biaya utang bank dengan biaya obligasi. WACC 1 menggunakan biaya utang (1) dikurangi effective tax rate. WACC 2 menggunakan biaya utang (1) dikurangi tingkat pajak standar. WACC 3 menggunakan biaya utang (2) dikurangi effective tax rate. WACC 4 menggunakan biaya utang (2) dikurangi tingkat pajak standar. Korelasi arus kas dihitung dari nilai rata-rata korelasi EBITDA antar segmen yang diabsolutkan selama 3 periode berturut-turut (periode $t_{-2}$ hingga $t_{0}$ ). Kendala pendanaan dihitung dengan variabel dummy (1 untuk yang tidak membayarkan dividen (mengalami kendala pendanaan), dan 0 untuk yang membayarkan dividen (tidak mengalami kendala pendanaan).

\section{Diversifikasi Usaha dan Biaya Modal}

Tabel 2 menunjukkan dari dua proxi diversifikasi usaha, hanya jumlah segmen yang berpengaruh signifikan terhadap biaya modal, namun dengan arah yang positif. Temuan ini mengindikasikan semakin terdiversifikasi suatu perusahaan, biaya modal secara rata-rata justru semakin meningkat. Indeks herfindahl juga menunjukkan pengaruh positif, namun tidak signifikan. Berdasarkan hasil tersebut, hipotesis pertama penelitian ini tidak terdukung. Hasil penelitian ini berbeda dengan Hann et. al. (2013) yang menemukan pengaruh negatif dari diversifikasi usaha terhadap biaya modal. Perbedaan arah pengaruh ini dapat dijelaskan dengan 3 alasan berdasarkan kerangka konseptual dan empiris yang dibangun dalam model penelitian ini.

Tabel 2. Hasil Regresi Diversifikasi Usaha dengan Biaya Modal

\begin{tabular}{|c|c|c|c|c|c|c|c|c|c|c|}
\hline & \multicolumn{2}{|c|}{ WACC 1} & \multicolumn{2}{|c|}{ WACC 2} & \multicolumn{2}{|c|}{ COD 1} & \multicolumn{2}{|c|}{$\mathrm{COD} 2$} & \multicolumn{2}{|c|}{$\mathrm{COE}$} \\
\hline & (1) & (2) & (1) & (2) & (1) & (2) & (1) & (2) & (1) & (2) \\
\hline Jumlah Segmen & $\begin{array}{l}0,01 \text { *** } \\
(3,22)\end{array}$ & & $\begin{array}{l}0,01^{* *} \\
(2,21)\end{array}$ & & $\begin{array}{l}-0,01 * \\
(1,86)\end{array}$ & & $\begin{array}{l}-0,01 \\
(0,47)\end{array}$ & & $\begin{array}{l}0,01 * * * \\
(3,44)\end{array}$ & \\
\hline Indeks Herfindahl & & $\begin{array}{l}0,02 \\
(1,29)\end{array}$ & & $\begin{array}{l}0,02 \\
(1,52)\end{array}$ & & $\begin{array}{l}-0,08^{* *} \\
(2,37)\end{array}$ & & $\begin{array}{l}-0,03 \\
(1,15)\end{array}$ & & $\begin{array}{l}0,04 * * \\
(2,07)\end{array}$ \\
\hline Leverage & $\begin{array}{l}-0,1 * * * \\
(6,37)\end{array}$ & $\begin{array}{l}-0,1 * * * \\
(7,08)\end{array}$ & $\begin{array}{l}-0,1 * * * \\
(6,43)\end{array}$ & $\begin{array}{l}-0,1 * * * \\
(7,46)\end{array}$ & $\begin{array}{l}-0,1 * * * \\
(2,83)\end{array}$ & $\begin{array}{l}-0,1 \text { *** } \\
(2,74)\end{array}$ & $\begin{array}{l}-0,1 * * * \\
(3,86)\end{array}$ & $\begin{array}{l}-0,1 * * * \\
(5,3)\end{array}$ & $\begin{array}{l}0,03^{*} \\
(1,82)\end{array}$ & $\begin{array}{l}0,03^{*} \\
(1,88)\end{array}$ \\
\hline Return on Assets & $\begin{array}{l}-0,02 \\
(1,38)\end{array}$ & $\begin{array}{l}-0,01 \\
(0,87)\end{array}$ & $\begin{array}{l}-0,02 \\
(1,22)\end{array}$ & $\begin{array}{l}-0,02 \\
(1,08)\end{array}$ & $\begin{array}{l}-0,03 \\
(1,13)\end{array}$ & $\begin{array}{l}-0,03 \\
(1,13)\end{array}$ & $\begin{array}{l}-0,04 \\
(1,32)\end{array}$ & $\begin{array}{l}0,05^{* *} \\
(2,1)\end{array}$ & $\begin{array}{l}0,02 \\
(1,42)\end{array}$ & $\begin{array}{l}0,03 * \\
(1,84)\end{array}$ \\
\hline Total & $\begin{array}{l}0,02 * * * \\
(6,64)\end{array}$ & $\begin{array}{l}0,02 * * * \\
(5,79)\end{array}$ & $\begin{array}{l}0,02^{* * *} \\
(5,87)\end{array}$ & $\begin{array}{l}0,02 * * * \\
(5,77)\end{array}$ & $\begin{array}{l}0,01 \\
(0,39)\end{array}$ & $\begin{array}{l}0,01 \\
(1,19)\end{array}$ & $\begin{array}{l}0,01 \\
(0,43)\end{array}$ & $\begin{array}{l}0,01 \\
(0,09)\end{array}$ & $\begin{array}{l}0,03^{* * *} \\
(6,5)\end{array}$ & $\begin{array}{l}0,03 * * * \\
(6,4)\end{array}$ \\
\hline Market to Book & $\begin{array}{l}-0,01 \\
(1,413)\end{array}$ & $\begin{array}{l}-0,01 \\
(1,41)\end{array}$ & $\begin{array}{l}-0,01 \\
(1,06)\end{array}$ & $\begin{array}{l}-0,01 \\
(1,13)\end{array}$ & $\begin{array}{l}0,01 * \\
(1,91)\end{array}$ & $\begin{array}{l}0,01^{*} \\
(1,79)\end{array}$ & $\begin{array}{l}0,01 \\
(1,47)\end{array}$ & $\begin{array}{l}0,01 \\
(0,88)\end{array}$ & $\begin{array}{l}-0,01 \\
(1,1)\end{array}$ & $\begin{array}{l}-0,01 \\
(0,24)\end{array}$ \\
\hline C & $\begin{array}{l}-0,5^{* * *} \\
(5,24) \\
\end{array}$ & $\begin{array}{l}-0,5^{* * *} \\
(4,4)\end{array}$ & $\begin{array}{l}-0,5^{* * *} \\
(4,5) \\
\end{array}$ & $\begin{array}{l}-0,4 * * * \\
(4,2)\end{array}$ & $\begin{array}{l}0,08 \\
(0,5)\end{array}$ & $\begin{array}{l}0,03 \\
(0,17)\end{array}$ & $\begin{array}{l}0,187 \\
(1,3)\end{array}$ & $\begin{array}{l}0,14 \\
(1,04)\end{array}$ & $\begin{array}{l}-0,9^{* * *} \\
(5,75)\end{array}$ & $\begin{array}{l}-0,8 * * * \\
(5,6)\end{array}$ \\
\hline $\mathrm{N}$ & 225 & 225 & 225 & 225 & 225 & 225 & 225 & 225 & 225 & 225 \\
\hline Obser. fixed effec & YES & YES & YES & YES & YES & YES & YES & YES & YES & YES \\
\hline Adjusted R2 & 0,86 & 0,83 & 0,85 & 0,86 & 0,65 & 0,68 & 0,69 & 0,74 & 0,76 & 0,77 \\
\hline
\end{tabular}

***,**,* berturut-turut signifikan pada $1 \%, 5 \%$, dan $10 \%$

Nilai $t$-statistic disajikan dalam kurung

Tabel 2 menyajikan hasil analisis regresi multivariat dengan 3 variabel dependen, yaitu biaya modal rata-rata (WACC), biaya utang, dan biaya ekuitas. Diversifikasi usaha sebagai variabel independen diukur dengan 2 proxy, yaitu jumlah segmen dan indeks herfindahl. Indeks herfindahl merupakan hasil kuadrat dari akumulasi penjualan tiap segmen dibagi dengan penjualan total dikurangi 1. 
Konsepco-insurance menjelaskan diversifikasi usaha akan menurunkan variabilitas arus kas sehingga menurunkan risiko perusahaan yang berdampak terhadap peningkatan kapasitas utang atau penurunan biaya utang. Di sisi lain, peningkatan utang akan meningkatkan risiko pemegang saham sehingga meningkatkan biaya ekuitas. Dengan adanya pengaruh ganda tersebut, maka dilakukan model pengujian terpisah antara biaya utang dan biaya ekuitas. Hasil pengujian mendukung hipotesis tersebut. Diversifikasi usaha berpengaruh negatif terhadap biaya utang dan berpengaruh positif terhadap biaya ekuitas. Jika mengacu pada nilai t-statistik, pengaruh diversifikasi terhadap peningkatan biaya ekuitas lebih kuat dibanding penurunan biaya utang. Oleh karena itu, secara rata-rata biaya modal justru semakin meningkat. Temuan Galai dan Masulis (1976), Higgins dan Schall (1975), serta Mansi dan Reeb (2002) yang menemukan adanya dampak ganda dari diversifikasi usaha mendukung hasil penelitian ini. Jika mengacu pada leverage perusahaan yang rata-rata hanya $36 \%$, bahkan ada yang tidak menggunakan utang, bisa jadi perusahaan belum mengoptimalkan kesempatan peningkatan kapasitas utang.

Alasan kedua dari perbedaan arah pengaruh tersebut dapat dijelaskan dengan teori keagenan dan pasar pendanaan internal sebagaimana dijelaskan oleh Amihud dan Lev (1999), Berger dan Ofek (1995), serta Mansi dan Reeb (2002). Mekanisme pendanaan internal pada perusahaan terdiversifikasi bisa meningkatkan biaya modal ketika terjadi konflik antar manajer divisi sehingga alokasi sumber daya menjadi tidak efisien. Konflik kepentingan yang terjadi bisa mempengaruhi keputusan transfer sumber daya yang tidak lagi didasarkan pada pertimbangan kinerja, namun bisa jadi faktor lain seperti kedekatan hubungan antar manajer divisi. Jika kebijakan subsidi silang tidak dilakukan secara efisien, diversifikasi justru akan meningkatkan risiko perusahaan. Sebagaimana ditunjukkan oleh Meyer, Milgrom dan Roberts (1992) kerugian yang dialami perusahaan tidak terdiversifikasi lebih rendah dibanding perusahaan terdiversifikasi, ketika subsidi silang sumber daya dilakukan dari unit bisnis yang kinerjanya bagus ke unit bisnis yang kinerjanya buruk.

Alasan ketiga, manfaatco-insurance dalam mengurangi risiko kebangkrutan akan sangat terasa dampaknya pada situasi krisis. Sedangkan pada situasi normal, risiko yang dihadapi perusahaan tidak terdiversifikasi bisa jadi sama dengan perusahaan terdiversifikasi. Namun, alasan kedua dan ketiga ini tidak didukung oleh hasil pengujian secara statistik karena keterbatasan data yang dimiliki peneliti. Hal ini diakui sebagai salah satu keterbatasan yang bisa dikembangkan untuk penelitian selanjutnya.

\section{Diversifikasi Usaha, Korelasi Arus Kas, dan Biaya Modal}

Sebagaimana dijelaskan sebelumnya, mekanisme pengaruh diversifikasi usaha terhadap biaya modal disebabkan oleh co-insurance effect. Salah satu cara untuk menguji apakah memang terjadi coinsurance effect atau tidak adalah dengan melihat hubungan biaya modal dengan korelasi arus kas (Franco et. al., 2010; Hann et. al., 2013). Jika semakin tinggi korelasi arus kas, biaya modal juga semakin meningkat, maka terjadi co-insurance effect. Hal ini dikarenakan tujuan utama dari coinsurance adalah mengurangi risiko perusahaan melalui pengurangan variabilitas arus kas. Semakin tinggi korelasi arus kas maka kemampuan diversifikasi dalam mengurangi variabilitas arus kas akan semakin rendah.

Hasil pada tabel 3 panel A -perusahaan dengan tingkat korelasi arus kas rendahmenunjukkan diversifikasi usaha berpengaruh positif terhadap biaya ekuitas dan biaya modal keseluruhan, dan berpengaruh negatif terhadap biaya utang. Namun pengaruh signifikan hanya ditunjukkan oleh jumlah segmen. Sedangkan indeks herfindahl menunjukkan arah pengaruh yang sama, namun tidak signifikan. Pada panel B -perusahaan yang memiliki korelasi arus kas tinggitidak ditemukan adanya pengaruh signifikan dari kedua proxi diversifikasi yang digunakan. Temuan tersebut mengindikasikan diversifikasi usaha pada perusahaan yang memiliki korelasi arus kas yang rendah antar segmennya memberikan manfaat co-insurance lebih besar. Hasil ini didukung oleh temuan Franco et. al. (2010), Hannet. al. (2013), serta Leland (2007). 
Tabel 3. Hasil Regresi Diversifikasi Usaha dan Korelasi Arus Kasterhadap Biaya Modal

\begin{tabular}{|c|c|c|c|c|c|c|c|c|c|c|}
\hline & \multicolumn{2}{|c|}{ WACC 1} & \multicolumn{2}{|c|}{ WACC 2} & \multicolumn{2}{|c|}{ COD 1} & \multicolumn{2}{|c|}{ COD 2} & \multicolumn{2}{|c|}{$\mathrm{COE}$} \\
\hline & $(1)$ & (2) & $(1)$ & $(2)$ & (1) & (2) & (1) & $(2)$ & (1) & $(2)$ \\
\hline \multicolumn{11}{|c|}{ Panel A. Korelasi Arus Kas Rendah } \\
\hline Jml Segmen & $\begin{array}{l}0,01 * * \\
(2,61)\end{array}$ & & $\begin{array}{l}0,01 * * \\
(2,24)\end{array}$ & & $\begin{array}{l}-0,01 * * \\
(2,27)\end{array}$ & & $\begin{array}{l}-0,01 * \\
(1,92)\end{array}$ & & $\begin{array}{l}0,01 * * * \\
(4,24)\end{array}$ & \\
\hline Indeks Herfindahl & & $\begin{array}{l}0,01 \\
(0,62)\end{array}$ & & $\begin{array}{l}0,01 \\
(0,77)\end{array}$ & & $\begin{array}{l}-0,08^{*} \\
(1,73)\end{array}$ & & $\begin{array}{l}-0,04 \\
(1,04)\end{array}$ & & $\begin{array}{l}0,02 \\
(0,96)\end{array}$ \\
\hline Leverage & $\begin{array}{l}-0,08 * * * \\
(5,05)\end{array}$ & $\begin{array}{l}-0,08 * * * \\
(5,05)\end{array}$ & $\begin{array}{l}-0,07 * * * \\
(4,27)\end{array}$ & $\begin{array}{l}-0,08 * * * \\
(4,72)\end{array}$ & $\begin{array}{l}-0,15^{* * *} \\
(3,09)\end{array}$ & $\begin{array}{l}-0,15^{* * *} \\
(3,02)\end{array}$ & $\begin{array}{l}-0,11^{* *} \\
(2,56)\end{array}$ & $\begin{array}{l}-0,11^{* *} \\
(2,45)\end{array}$ & $\begin{array}{l}0,03 * \\
(1,82)\end{array}$ & $\begin{array}{l}0,03 * \\
(1,71)\end{array}$ \\
\hline Return on Assets & $\begin{array}{l}-0,01 \\
(0,56)\end{array}$ & $\begin{array}{l}-0,01 \\
(0,48)\end{array}$ & $\begin{array}{l}-0,01 \\
(0,18)\end{array}$ & $\begin{array}{l}-0,01 \\
(0,27)\end{array}$ & $\begin{array}{l}0,01 \\
(0,13)\end{array}$ & $\begin{array}{l}0,03 \\
(0,6)\end{array}$ & $\begin{array}{l}0,01 \\
(0,14)\end{array}$ & $\begin{array}{l}0,02 \\
(0,32)\end{array}$ & $\begin{array}{l}-0,01 \\
(0,34)\end{array}$ & $\begin{array}{l}0,04 \\
(0,02)\end{array}$ \\
\hline Total Aset(Ln) & $\begin{array}{l}0,02 * * * \\
(5,14)\end{array}$ & $\begin{array}{l}0,02 * * * \\
(4,18)\end{array}$ & $\begin{array}{l}0,02 * * * \\
(5,02)\end{array}$ & $\begin{array}{l}0,02 * * * \\
(4,11)\end{array}$ & $\begin{array}{l}-0,02 * * \\
(2,05)\end{array}$ & $\begin{array}{l}-0,01 \\
(1,38)\end{array}$ & $\begin{array}{l}-0,02 * * \\
(2,3)\end{array}$ & $\begin{array}{l}-0,01 * \\
(1,73)\end{array}$ & $\begin{array}{l}0,04 * * * \\
(6,37)\end{array}$ & $\begin{array}{l}0,04 * * * \\
(5,65)\end{array}$ \\
\hline Book to Market & $\begin{array}{l}-0,01 \\
(0,98)\end{array}$ & $\begin{array}{l}-0,01 \\
(0,79)\end{array}$ & $\begin{array}{l}-0,01 \\
(0,62)\end{array}$ & $\begin{array}{l}-0,01 \\
(0,62)\end{array}$ & $\begin{array}{l}0,01 \\
(1,36)\end{array}$ & $\begin{array}{l}0,01 \\
(1,22)\end{array}$ & $\begin{array}{l}0,01^{*} \\
(1,74)\end{array}$ & $\begin{array}{l}0,01 \\
(1,52)\end{array}$ & $\begin{array}{l}-0,01 \\
(1,05)\end{array}$ & $\begin{array}{l}-0,01 \\
(0,47)\end{array}$ \\
\hline $\mathrm{C}$ & $\begin{array}{l}-0,6 * * * \\
(4,09)\end{array}$ & $\begin{array}{l}-0,5^{* * *} \\
(3,19)\end{array}$ & $\begin{array}{l}-0,55 * * * \\
(3,94)\end{array}$ & $\begin{array}{l}-0,45 * * * \\
(3,06)\end{array}$ & $\begin{array}{l}0,87 * * * \\
(2,65)\end{array}$ & $\begin{array}{l}0,65^{*} \\
(1,91)\end{array}$ & $\begin{array}{l}0,78 * * * \\
(2,91)\end{array}$ & $\begin{array}{l}0,6 * * \\
(2,28) \\
\end{array}$ & $\begin{array}{l}-1,13 * * * \\
(5,74)\end{array}$ & $\begin{array}{l}-0,98 * * * \\
(4,93)\end{array}$ \\
\hline $\mathrm{N}$ & 105 & 105 & 105 & 105 & 105 & 105 & 105 & 105 & 105 & 105 \\
\hline Obs. & YES & YES & YES & YES & YES & YES & YES & YES & YES & YES \\
\hline Adjusted R2 & 0,84 & 0,82 & 0,85 & 0,83 & 0,6 & 0,57 & 0,62 & 0,61 & 0,77 & 0,74 \\
\hline \multicolumn{11}{|c|}{ Panel B. Korelasi Arus Kas Tinggi } \\
\hline Jml Segmen & $\begin{array}{l}0,01 \\
(1,59)\end{array}$ & & $\begin{array}{l}0,01 \\
(0,94)\end{array}$ & & $\begin{array}{l}0,01 \\
(0,32)\end{array}$ & & $\begin{array}{l}-0,01 \\
(0,11)\end{array}$ & & $\begin{array}{l}0,01 * \\
(1,83)\end{array}$ & \\
\hline Indeks Herfindahl & & $\begin{array}{l}0,03 \\
(0,77)\end{array}$ & & $\begin{array}{l}0,03 \\
(0,95)\end{array}$ & & $\begin{array}{l}-0,03 \\
(0,73)\end{array}$ & & $\begin{array}{l}0,01 \\
(0,21)\end{array}$ & & $\begin{array}{l}0,06 \\
(1,59)\end{array}$ \\
\hline Leverage & $\begin{array}{l}-0,08 * * * \\
(3,47)\end{array}$ & $\begin{array}{l}-0,09 * * * \\
(3,79)\end{array}$ & $\begin{array}{l}-0,1 * * * \\
(4,25)\end{array}$ & $\begin{array}{l}-0,1 * * * \\
(4,42)\end{array}$ & $\begin{array}{l}-0,02 \\
(0,68)\end{array}$ & $\begin{array}{l}-0,02 \\
(0,64)\end{array}$ & $\begin{array}{l}-0,05^{*} \\
(1,86)\end{array}$ & $\begin{array}{l}-0,04 * \\
(1,82)\end{array}$ & $\begin{array}{l}0,01 \\
(0,12)\end{array}$ & $\begin{array}{l}-0,01 \\
(0,16)\end{array}$ \\
\hline Return on Assets & $\begin{array}{l}-0,03 \\
(1,15)\end{array}$ & $\begin{array}{l}-0,03 \\
(1,08)\end{array}$ & $\begin{array}{l}-0,04 \\
(1,35)\end{array}$ & $\begin{array}{l}-0,03 \\
(1,15)\end{array}$ & $\begin{array}{l}-0,04 \\
(1,1)\end{array}$ & $\begin{array}{l}-0,04 \\
(1,02)\end{array}$ & $\begin{array}{l}-0,04 \\
(1,06)\end{array}$ & $\begin{array}{l}-0,03 \\
(0,86)\end{array}$ & $\begin{array}{l}0,04 * * \\
(2,19)\end{array}$ & $\begin{array}{l}0,05^{*} \\
(1,9)\end{array}$ \\
\hline Total Aset (Ln) & $\begin{array}{l}0,02 * * \\
(2,29)\end{array}$ & $\begin{array}{l}0,01 * * \\
(2,08)\end{array}$ & $\begin{array}{l}0,01 * * \\
(2,02)\end{array}$ & $\begin{array}{l}0,01 \\
(1,65)\end{array}$ & $\begin{array}{l}0,01 \\
(0,88)\end{array}$ & $\begin{array}{l}0,01 \\
(1,22)\end{array}$ & $\begin{array}{l}0,01 \\
(0,53)\end{array}$ & $\begin{array}{l}0,01 \\
(0,84)\end{array}$ & $\begin{array}{l}0,03 * * * \\
(3,11)\end{array}$ & $\begin{array}{l}0,02 * * \\
(2,16)\end{array}$ \\
\hline Book to Market & $\begin{array}{l}-0,01 \\
(1,56)\end{array}$ & $\begin{array}{l}-0,01 * \\
(1,73)\end{array}$ & $\begin{array}{l}-0,01 * \\
(1,79)\end{array}$ & $\begin{array}{l}-0,01 * \\
(1,84)\end{array}$ & $\begin{array}{l}0,01 \\
(1,17)\end{array}$ & $\begin{array}{l}0,01 \\
(1,51)\end{array}$ & $\begin{array}{l}0,01 \\
(0,56)\end{array}$ & $\begin{array}{l}0,01 \\
(0,88)\end{array}$ & $\begin{array}{l}-0,01 \\
(0,72)\end{array}$ & $\begin{array}{l}-0,01 \\
(0,8)\end{array}$ \\
\hline $\mathrm{C}$ & $\begin{array}{l}-0,39 * \\
(1,72)\end{array}$ & $\begin{array}{l}-0,32 \\
(1,44)\end{array}$ & $\begin{array}{l}-0,29 \\
(1,33)\end{array}$ & $\begin{array}{l}-0,18 \\
(0,92)\end{array}$ & $\begin{array}{l}-0,13 \\
(0,53)\end{array}$ & $\begin{array}{l}-0,16 \\
(0,76)\end{array}$ & $\begin{array}{l}-0,02 \\
(0,09)\end{array}$ & $\begin{array}{l}-0,08 \\
(0,37)\end{array}$ & $\begin{array}{l}-0,69 * * * \\
(2,69) \\
\end{array}$ & $\begin{array}{l}-0,45^{*} \\
(1,77)\end{array}$ \\
\hline $\mathrm{N}$ & 120 & 120 & 120 & 120 & 120 & 120 & 120 & 120 & 120 & 120 \\
\hline Obs. Fix. Ef & YES & YES & YES & YES & YES & YES & YES & YES & YES & YES \\
\hline Adjusted R2 & 0,67 & 0,66 & 0,66 & 0,66 & 0,64 & 0,67 & 0,61 & 0,64 & 0,69 & 0,67 \\
\hline
\end{tabular}

$* * *, * *, *$ berturut-turut signifikan pada $1 \%, 5 \%$, dan $10 \%$

Nilai $t$-statistic disajikan dalam kurung

\section{Diversifikasi Usaha, Kendala Pendanaan, dan Biaya Modal}

Selanjutnya dilakukan pengujian dengan pemisahan sampel ke dalam dua kategori, yaitu financially constrained dan unfinancially constrained berdasarkan rasio pembayaran dividen, rasio likuiditas, dan coverage ratio. Dalam pengklasifikasian, nilai median digunakan sebagai cut-off. Perusahaan yang memiliki rasio di bawah nilai cut-off dianggap financially constrained atau mengalami kendala pendanaan. Untuk peringkat obligasi, karena terbatasnya jumlah perusahaan yang menerbitkan obligasi, hanya 18 dari 45 perusahaan, maka tidak dilakukan pemisahan sampel. Berdasarkan hasil pengujian, tidak ditemukan adanya pengaruh signifikan secara konsisten pada keseluruhan model untuk variabel peringkat obligasi, baik dengan maupun tanpa interaksi. Hal ini bisa jadi disebabkan oleh terbatasnya jumlah perusahaan sampel yang menerbitkan obligasi.

Tabel 4 panel A menunjukkan diversifikasi usaha berpengaruh signifikan terhadap biaya modal secara konsisten, baik dilihat dari jumlah segmen maupun indeks herfindahl, pada perusahaan yang memiliki rasio pembayaran dividen yang rendah. Sebaliknya, pada panel B yang terdiri dari perusahaan dengan rasio pembayaran dividen tinggi tidak ditemukan adanya pengaruh 
signifikan pada keseluruhan model. Hal ini mengindikasikan manfaat diversikasi usaha lebih terlihat ketika perusahaan mengalami kendala pendanaan tinggi.

Tabel 4. Hasil Regresi Diversifikasi Usaha dan Rasio Pembayaran Dividenterhadap Biaya Modal

\begin{tabular}{|c|c|c|c|c|c|c|c|c|c|c|}
\hline & \multicolumn{2}{|c|}{ WACC 1} & \multicolumn{2}{|c|}{ WACC 2} & \multicolumn{2}{|c|}{ COD 1} & \multicolumn{2}{|c|}{ COD 2} & \multicolumn{2}{|c|}{$\mathrm{COE}$} \\
\hline & $(1)$ & $(2)$ & $(1)$ & (2) & $(1)$ & (2) & $(1)$ & $(2)$ & $(1)$ & $(2)$ \\
\hline \multicolumn{11}{|c|}{ Panel A. Low Dividen Payout (Financially Constrained) } \\
\hline Jumlah Segmen & $\begin{array}{l}0,01 * * * \\
(3,01)\end{array}$ & & $\begin{array}{l}0,01 * * * \\
(2,64)\end{array}$ & & $\begin{array}{l}-0,01^{* *} \\
(2,31\end{array}$ & & $\begin{array}{l}-0,01 * \\
(1,77)\end{array}$ & & $\begin{array}{l}0,01 * * * \\
(3,5)\end{array}$ & \\
\hline IndeksHerfindahl & & $\begin{array}{l}0,03 * * \\
(2,03)\end{array}$ & & $\begin{array}{l}0,03 * * \\
(2,24)\end{array}$ & & $\begin{array}{l}-0,03 \\
(1,13)\end{array}$ & & $\begin{array}{l}0,01 \\
(0,28)\end{array}$ & & $\begin{array}{l}0,04 * \\
(1,82)\end{array}$ \\
\hline Leverage & $\begin{array}{l}-0,08 * * * \\
(5,92)\end{array}$ & $\begin{array}{l}-0,09 * * * \\
(6,26)\end{array}$ & $\begin{array}{l}-0,09 * * * \\
(6,3)\end{array}$ & $\begin{array}{l}-0,09 * * * \\
(6,86)\end{array}$ & $\begin{array}{l}-0,03 * \\
(1,8)\end{array}$ & $\begin{array}{l}-0,03 * \\
(1,66)\end{array}$ & $\begin{array}{l}-0,05 * * * \\
(3,24)\end{array}$ & $\begin{array}{l}-0,05^{* * *} \\
(3,19)\end{array}$ & $\begin{array}{l}0,02 \\
(1,15)\end{array}$ & $\begin{array}{l}0,02 \\
(0,96)\end{array}$ \\
\hline Return on Assets & $\begin{array}{l}-0,01 \\
(0,93)\end{array}$ & $\begin{array}{l}-0,01 \\
(0,85)\end{array}$ & $\begin{array}{l}-0,01 \\
(0,88)\end{array}$ & $\begin{array}{l}0,02 \\
(1,04)\end{array}$ & $\begin{array}{l}-0,01 \\
(0,48)\end{array}$ & $\begin{array}{l}-0,01 \\
(0,68)\end{array}$ & $\begin{array}{l}-0,01 \\
(0,13)\end{array}$ & $\begin{array}{l}0,01 \\
(0,24)\end{array}$ & $\begin{array}{l}0,03^{*} \\
(1,81)\end{array}$ & $\begin{array}{l}0,03 \\
(1,43)\end{array}$ \\
\hline Total Aset (Ln) & $\begin{array}{l}0,02 * * * \\
(5,6)\end{array}$ & $\begin{array}{l}0,02 * * * \\
(5,14)\end{array}$ & $\begin{array}{l}0,02 * * * \\
(4,87)\end{array}$ & $\begin{array}{l}0,02 * * * \\
(4,72)\end{array}$ & $\begin{array}{l}-0,01 \\
(0,1)\end{array}$ & $\begin{array}{l}-0,01 \\
(0,55)\end{array}$ & $\begin{array}{l}-0,01 \\
(1,13)\end{array}$ & $\begin{array}{l}-0,01 \\
(1,48)\end{array}$ & $\begin{array}{l}0,03 * * * \\
(4,84)\end{array}$ & $\begin{array}{l}0,02 * * * \\
(4,21)\end{array}$ \\
\hline Market to book & $\begin{array}{l}-0,01 * \\
(1,74)\end{array}$ & $\begin{array}{l}-0,01 \\
(1,52)\end{array}$ & $\begin{array}{l}-0,01 \\
(1,46)\end{array}$ & $\begin{array}{l}-0,01 \\
(1,44)\end{array}$ & $\begin{array}{l}0,01 * * * \\
(3,37)\end{array}$ & $\begin{array}{l}0,01 * * * \\
(3,06)\end{array}$ & $\begin{array}{l}0,01 * * \\
(2,4)\end{array}$ & $\begin{array}{l}0,01 * * \\
(2,18)\end{array}$ & $\begin{array}{l}-0,01 * \\
(1,78)\end{array}$ & $\begin{array}{l}-0,01 \\
(0,66)\end{array}$ \\
\hline $\mathrm{C}$ & $\begin{array}{l}-0,62 * * * \\
(4,63)\end{array}$ & $\begin{array}{l}-0,51 * * * \\
(3,99)\end{array}$ & $\begin{array}{l}-0,48 * * * \\
(3,8)\end{array}$ & $\begin{array}{l}-0,44 * * * \\
(3,55)\end{array}$ & $\begin{array}{l}0,13 \\
(1,4)\end{array}$ & $\begin{array}{l}0,04 \\
(0,39)\end{array}$ & $\begin{array}{l}0,22 * * \\
(2,26) \\
\end{array}$ & $\begin{array}{l}0,2 * * * \\
(2,64) \\
\end{array}$ & $\begin{array}{l}-0,78 * * * \\
(4,27)\end{array}$ & $\begin{array}{l}-0,6 * * * \\
(3,51)\end{array}$ \\
\hline $\mathrm{N}$ & 150 & 150 & 150 & 150 & 150 & 150 & 150 & 150 & 150 & 150 \\
\hline Obser. fixed effec & YES & YES & YES & YES & YES & YES & YES & YES & YES & YES \\
\hline Adjusted R2 & 0,83 & 0,86 & 0,85 & 0,87 & 0,84 & 0,81 & 0,88 & 0,82 & 0,74 & 0,77 \\
\hline \multicolumn{11}{|c|}{ Panel B. High Dividen Payout (Unfinancially Constrained) } \\
\hline Jumlah Segmen & $\begin{array}{l}-0,01 \\
(0,16)\end{array}$ & & $\begin{array}{l}-0,01 \\
(0,09)\end{array}$ & & $\begin{array}{l}-0,01 \\
(0,26)\end{array}$ & & $\begin{array}{l}-0,01 \\
(0,32)\end{array}$ & & $\begin{array}{l}-0,01 \\
(0,52)\end{array}$ & \\
\hline Indeks Herfindahl & & $\begin{array}{l}-0,04 \\
(1,51)\end{array}$ & & $\begin{array}{l}-0,05 \\
(1,65)\end{array}$ & & $\begin{array}{l}-0,02 \\
(0,17)\end{array}$ & & $\begin{array}{l}-0,01 \\
(0,07)\end{array}$ & & $\begin{array}{l}-0,01 \\
(0,13)\end{array}$ \\
\hline Leverage & $\begin{array}{l}-0,01 \\
(0,45)\end{array}$ & $\begin{array}{l}-0,01 \\
(0,08)\end{array}$ & $\begin{array}{l}-0,02 \\
(0,63)\end{array}$ & $\begin{array}{l}-0,01 \\
(0,04)\end{array}$ & $\begin{array}{l}-0,1 \\
(1,26)\end{array}$ & $\begin{array}{l}-0,06 \\
(0,72)\end{array}$ & $\begin{array}{l}-0,1 \\
(1,27)\end{array}$ & $\begin{array}{l}-0,05 \\
(0,68)\end{array}$ & $\begin{array}{l}0,06^{*} \\
(1,67)\end{array}$ & $\begin{array}{l}0,06 \\
(1,6)\end{array}$ \\
\hline Return on Assets & $\begin{array}{l}0,04 \\
(0,58)\end{array}$ & $\begin{array}{l}0,09 \\
(1,22)\end{array}$ & $\begin{array}{l}0,02 \\
(0,36)\end{array}$ & $\begin{array}{l}0,07 \\
(0,99)\end{array}$ & $\begin{array}{l}-0,27 * \\
(1,77)\end{array}$ & $\begin{array}{l}-0,22 \\
(1,27)\end{array}$ & $\begin{array}{l}-0,32 * * \\
(2,37)\end{array}$ & $\begin{array}{l}-0,28 * \\
(1,74)\end{array}$ & $\begin{array}{l}0,16^{*} \\
(1,73)\end{array}$ & $\begin{array}{l}0,15 \\
(1,65)\end{array}$ \\
\hline Total Aset (Ln) & $\begin{array}{l}0,01 \\
(1,24)\end{array}$ & $\begin{array}{l}0,01 \\
(1,55)\end{array}$ & $\begin{array}{l}0,01 \\
(1,24)\end{array}$ & $\begin{array}{l}0,01 \\
(1,57)\end{array}$ & $\begin{array}{l}-0,04^{*} \\
(1,94)\end{array}$ & $\begin{array}{l}-0,04 * \\
(1,91)\end{array}$ & $\begin{array}{l}-0,05^{* *} \\
(2,36)\end{array}$ & $\begin{array}{l}-0,05^{* *} \\
(2,29)\end{array}$ & $\begin{array}{l}0,04 * * * \\
(3,46)\end{array}$ & $\begin{array}{l}0,04 * * * \\
(3,55)\end{array}$ \\
\hline Market to book & $\begin{array}{l}0,01 \\
(1,08)\end{array}$ & $\begin{array}{l}0,01 \\
(0,89)\end{array}$ & $\begin{array}{l}0,01 \\
(1,13)\end{array}$ & $\begin{array}{l}0,01 \\
(0,94)\end{array}$ & $\begin{array}{l}-0,01 \\
(0,82)\end{array}$ & $\begin{array}{l}-0,01 \\
(0,61)\end{array}$ & $\begin{array}{l}-0,01 \\
(1,14)\end{array}$ & $\begin{array}{l}-0,01 \\
(0,87)\end{array}$ & $\begin{array}{l}0,01 \\
(0,95)\end{array}$ & $\begin{array}{l}0,01 \\
(1,03)\end{array}$ \\
\hline $\mathrm{C}$ & $\begin{array}{l}-0,2 \\
(0,76)\end{array}$ & $\begin{array}{l}-0,27 \\
(1,02)\end{array}$ & $\begin{array}{l}-0,19 \\
(0,73)\end{array}$ & $\begin{array}{l}-0,26 \\
(1,02) \\
\end{array}$ & $\begin{array}{l}1,44 * * \\
(2,28)\end{array}$ & $\begin{array}{l}1,47 * * \\
(2,18) \\
\end{array}$ & $\begin{array}{l}1,6 * * * \\
(2,72) \\
\end{array}$ & $\begin{array}{l}1,6 \\
(2,55)\end{array}$ & $\begin{array}{l}-1,1 * * * \\
(3,13)\end{array}$ & $\begin{array}{l}-1,14 * * * \\
(3,25)\end{array}$ \\
\hline $\mathrm{N}$ & 75 & 75 & 75 & 75 & 75 & 75 & 75 & 75 & 75 & 75 \\
\hline Obser. fixed effec & YES & YES & YES & YES & YES & YES & YES & YES & YES & YES \\
\hline Adjusted R2 & 0,63 & 0,62 & 0,65 & 0,63 & 0,56 & 0,52 & 0,57 & 0,53 & 0,66 & 0,66 \\
\hline
\end{tabular}

Hasil selaras ditemukan ketika kendala pendanaan diklasifikasikan berdasarkan coverage ratio. Hasil pengujian pada tabel 5 menunjukkan diversifikasi usaha hanya berpengaruh terhadap biaya modal pada perusahaan yang memiliki coverage ratio yang rendah (mengalami kendala pendanaan). Namun pengaruh yang signifikan dan terjadi secara konsisten hanya ditunjukkan oleh variabel jumlah segmen. Sebaliknya, ketika diversifikasi usaha diuji pada perusahaan dengan coverage ratio yang tinggi (tidak mengalami kendala pendanaan) tidak ditemukan adanya pengaruh yang signifikan dalam pengurangan biaya modal sebagaimana ditunjukkan pada panel B. 
Tabel 5. Hasil Regresi Diversifikasi Usaha dan Coverage Ratioterhadap Biaya Modal

\begin{tabular}{|c|c|c|c|c|c|c|c|c|c|c|}
\hline & \multicolumn{2}{|l|}{ WACC 1} & \multicolumn{2}{|l|}{ WACC 2} & \multicolumn{2}{|l|}{ COD 1} & \multicolumn{2}{|l|}{ COD2 } & \multicolumn{2}{|l|}{$\mathrm{COE}$} \\
\hline & $(1)$ & $(2)$ & $(1)$ & $(2)$ & $(1)$ & $(2)$ & $(1)$ & $(2)$ & $(1)$ & $(2)$ \\
\hline \multicolumn{11}{|c|}{ Panel A. Low Coverage Ratio (Financially Constrained) } \\
\hline JumlahSegmen & $\begin{array}{l}0,02 * * * \\
(4,46)\end{array}$ & & $\begin{array}{l}0,02 * * * \\
(3,49)\end{array}$ & & $\begin{array}{l}-0,01 * * \\
(2,07)\end{array}$ & & $\begin{array}{l}-0,01 * \\
(1,82)\end{array}$ & & $\begin{array}{l}0,02 * * * \\
(5,14)\end{array}$ & \\
\hline Indeks Herfindahl & & $\begin{array}{l}0,06 \\
(1,65)\end{array}$ & & $\begin{array}{l}0,07^{* *} \\
(2,21)\end{array}$ & & $\begin{array}{l}0,01 \\
(0,11)\end{array}$ & & $\begin{array}{l}0,03 \\
(1,29)\end{array}$ & & $\begin{array}{l}0,05 \\
(1,42)\end{array}$ \\
\hline Leverage & $\begin{array}{l}-0,06 * * * \\
(3,27)\end{array}$ & $\begin{array}{l}-0,07 * * * \\
(3,57)\end{array}$ & $\begin{array}{l}-0,07 * * * \\
(3,78)\end{array}$ & $\begin{array}{l}-0,08 * * * \\
(4,28)\end{array}$ & $\begin{array}{l}-0,01 \\
(0,59)\end{array}$ & $\begin{array}{l}-0,01 \\
(0,32)\end{array}$ & $\begin{array}{l}-0,01 \\
(0,730\end{array}$ & $\begin{array}{l}-0,01 \\
(0,96)\end{array}$ & $\begin{array}{l}0,05^{* *} \\
(2,55)\end{array}$ & $\begin{array}{l}0,03 \\
(1,3)\end{array}$ \\
\hline Return on Assets & $\begin{array}{l}-0,01 \\
(0,36)\end{array}$ & $\begin{array}{l}-0,03 \\
(1,240\end{array}$ & $\begin{array}{l}-0,01 \\
(0,19)\end{array}$ & $\begin{array}{l}-0,02 \\
(0,88)\end{array}$ & $\begin{array}{l}-0,03 \\
(1,290\end{array}$ & $\begin{array}{l}-0,03 \\
(1,21)\end{array}$ & $\begin{array}{l}-0,02 \\
(0,91)\end{array}$ & $\begin{array}{l}-0,01 \\
(0,48)\end{array}$ & $\begin{array}{l}0,05^{* * *} \\
(3,46)\end{array}$ & $\begin{array}{l}0,04 \\
(1,51)\end{array}$ \\
\hline Total Aset (Ln) & $\begin{array}{l}0,02 * * * \\
(3,03)\end{array}$ & $\begin{array}{l}0,01 * \\
(1,77)\end{array}$ & $\begin{array}{l}0,02 * * \\
(2,48)\end{array}$ & $\begin{array}{l}0,01 \\
(1,16)\end{array}$ & $\begin{array}{l}0,01 \\
(1,09)\end{array}$ & $\begin{array}{l}0,01 \\
(1,25)\end{array}$ & $\begin{array}{l}0,01 \\
(0,56)\end{array}$ & $\begin{array}{l}0,01 \\
(0,19)\end{array}$ & $\begin{array}{l}0,02 * * * \\
(3,67)\end{array}$ & $\begin{array}{l}0,01 \\
(0,94)\end{array}$ \\
\hline Market to book & $\begin{array}{l}-0,01 * \\
(1,67)\end{array}$ & $\begin{array}{l}-0,01 \\
(1,070\end{array}$ & $\begin{array}{l}-0,01 \\
(1,38)\end{array}$ & $\begin{array}{l}-0,01 \\
(1,06)\end{array}$ & $\begin{array}{l}0,01 * * * \\
(3,17)\end{array}$ & $\begin{array}{l}0,01 * * * \\
(3,3)\end{array}$ & $\begin{array}{l}0,01 * * \\
(2,46)\end{array}$ & $\begin{array}{l}0,01 * * \\
(2,44)\end{array}$ & $\begin{array}{l}-0,01 * * \\
(2,6)\end{array}$ & $\begin{array}{l}-0,01 \\
(1,01)\end{array}$ \\
\hline $\mathrm{C}$ & $\begin{array}{l}-0,54 * * * \\
(2,65)\end{array}$ & $\begin{array}{l}-0,31 \\
(1,31) \\
\end{array}$ & $\begin{array}{l}-0,42 * * \\
(2,03) \\
\end{array}$ & $\begin{array}{l}-0,13 \\
(0,62) \\
\end{array}$ & $\begin{array}{l}0,01 \\
(0,11)\end{array}$ & $\begin{array}{l}0,05 \\
(0,49)\end{array}$ & $\begin{array}{l}0,06 \\
(0,63)\end{array}$ & $\begin{array}{l}0,05 \\
(0,58) \\
\end{array}$ & $\begin{array}{l}-0,73 * * * \\
(3,44)\end{array}$ & $\begin{array}{l}-0,15 \\
(0,6) \\
\end{array}$ \\
\hline $\mathrm{N}$ & 115 & 115 & 115 & 115 & 115 & 115 & 115 & 115 & 115 & 115 \\
\hline Obser. fixed effec & YES & YES & YES & YES & YES & YES & YES & YES & YES & YES \\
\hline Adjusted R2 & 0,5 & 0,41 & 0,53 & 0,52 & 0,87 & 0,86 & 0,87 & 0,86 & 0,71 & 0,64 \\
\hline \multicolumn{11}{|c|}{ Panel B. High Coverage Ratio (Unfinancially Constrained) } \\
\hline Jumlah Segmen & $\begin{array}{l}0,01 \\
(1,39)\end{array}$ & & $\begin{array}{l}0,01 \\
(1,45)\end{array}$ & & $\begin{array}{l}-0,01 * \\
(1,91)\end{array}$ & & $\begin{array}{l}-0,01 \\
(1,4)\end{array}$ & & $\begin{array}{l}0,01 * * * \\
(3,47)\end{array}$ & \\
\hline Indeks Herfindahl & & $\begin{array}{l}0,01 \\
(0,77)\end{array}$ & & $\begin{array}{l}0,01 \\
(0,76)\end{array}$ & & $\begin{array}{l}-0,12 * * \\
(2,15)\end{array}$ & & $\begin{array}{l}-0,1 * \\
(1,87)\end{array}$ & & $\begin{array}{l}0,02 \\
(1,05)\end{array}$ \\
\hline Leverage & $\begin{array}{l}-0,09 * * * \\
(5,57)\end{array}$ & $\begin{array}{l}-0,09 * * * \\
(6,05)\end{array}$ & $\begin{array}{l}-0,09 * * * \\
(5,42)\end{array}$ & $\begin{array}{l}-0,09 * * * \\
(5,69)\end{array}$ & $\begin{array}{l}-0,21 * * * \\
(3,07)\end{array}$ & $\begin{array}{l}-0,19 * * * \\
(2,65)\end{array}$ & $\begin{array}{l}-0,17 * * * \\
(2,72)\end{array}$ & $\begin{array}{l}-0,15 * * \\
(2,41)\end{array}$ & $\begin{array}{l}0,03 \\
(1,46)\end{array}$ & $\begin{array}{l}0,03 \\
(1,3)\end{array}$ \\
\hline Return on Assets & $\begin{array}{l}-0,02 \\
(1,05)\end{array}$ & $\begin{array}{l}-0,01 \\
(0,56)\end{array}$ & $\begin{array}{l}-0,03 \\
(1,39)\end{array}$ & $\begin{array}{l}-0,02 \\
(0,93)\end{array}$ & $\begin{array}{l}-0,05 \\
(0,58)\end{array}$ & $\begin{array}{l}-0,04 \\
(0,46)\end{array}$ & $\begin{array}{l}-0,03 \\
(0,41)\end{array}$ & $\begin{array}{l}-0,04 \\
(0,61)\end{array}$ & $\begin{array}{l}-0,01 \\
(0,41)\end{array}$ & $\begin{array}{l}-0,01 \\
(0,13)\end{array}$ \\
\hline Total Aset (Ln) & $\begin{array}{l}0,03^{* * *} \\
(5,16)\end{array}$ & $\begin{array}{l}0,03 * * * \\
(4,92)\end{array}$ & $\begin{array}{l}0,02 * * * \\
(4,73)\end{array}$ & $\begin{array}{l}0,02 * * * \\
(4,49)\end{array}$ & $\begin{array}{l}-0,01 \\
(0,01)\end{array}$ & $\begin{array}{l}-0,01 \\
(0,11)\end{array}$ & $\begin{array}{l}-0,01 \\
(0,57)\end{array}$ & $\begin{array}{l}-0,01 \\
(0,65)\end{array}$ & $\begin{array}{l}0,04^{* * *} \\
(7,31)\end{array}$ & $\begin{array}{l}0,04 * * * \\
(6,17)\end{array}$ \\
\hline Market to book & $\begin{array}{l}0,01 \\
(0,47)\end{array}$ & $\begin{array}{l}0,01 \\
(0,29)\end{array}$ & $\begin{array}{l}0,01 \\
(0,41)\end{array}$ & $\begin{array}{l}0,01 \\
(0,29)\end{array}$ & $\begin{array}{l}0,01 \\
(1,15)\end{array}$ & $\begin{array}{l}0,01 \\
(1,3)\end{array}$ & $\begin{array}{l}0,01 \\
(0,5)\end{array}$ & $\begin{array}{l}0,01 \\
(0,68)\end{array}$ & $\begin{array}{l}0,01 \\
(1,4)\end{array}$ & $\begin{array}{l}0,01 \\
(1,4)\end{array}$ \\
\hline $\mathrm{C}$ & $\begin{array}{l}-0,67 * * * \\
(4,28)\end{array}$ & $\begin{array}{l}-0,64 * * * \\
(4)\end{array}$ & $\begin{array}{l}-0,62 * * * \\
(3,870\end{array}$ & $\begin{array}{l}-0,6 * * * \\
(3,59)\end{array}$ & $\begin{array}{l}0,18 \\
(0,53)\end{array}$ & $\begin{array}{l}0,15 \\
(0,42)\end{array}$ & $\begin{array}{l}0,33 \\
(1,12) \\
\end{array}$ & $\begin{array}{l}0,36 \\
(1,22) \\
\end{array}$ & $\begin{array}{l}-1,26 * * * \\
(6,71)\end{array}$ & $\begin{array}{l}-1,16^{* * *} \\
(5,54)\end{array}$ \\
\hline $\mathrm{N}$ & 110 & 110 & 110 & 110 & 110 & 110 & 110 & 110 & 110 & 110 \\
\hline Obser. fixed effec & YES & YES & YES & YES & YES & YES & YES & YES & YES & YES \\
\hline Adjusted R2 & 0,86 & 0,86 & 0,85 & 0,85 & 0,59 & 0,61 & 0,59 & 0,64 & 0,85 & 0,81 \\
\hline
\end{tabular}

Hasil pemisahan sampel berdasarkan rasio likuiditas pada tabel 6 juga menunjukkan adanya konsistensi pengaruh kendala pendanaan terhadap diversifikasi usaha dan biaya modal. Tingkat signifikansi juga cukup tinggi untuk keseluruhan model ( $\alpha$ 1\%), khususnya ketika diversifikasi usaha diukur menggunakan jumlah segmen (Panel A).

Ketiga proxi kendala pendanaan yang digunakan secara konsisten menunjukkan adanya dukungan yang kuat untuk menerima hipotesis ketiga, di mana hasil pengujian menunjukkan pengaruh diversifikasi usaha terhadap biaya modal akan semakin kuat pada perusahaan yang mengalami kendala pendanaan tinggi. Hasil ini mendukung penelitian sebelumnya dari Kuppuswamy dan Villalonga (2010), Matsusaka dan Nanda (2002), Stein (1997), serta Yan (2006). 
Tabel 6. Hasil Regresi Diversifikasi Usaha danRasio Likuiditas terhadap Biaya Modal

\begin{tabular}{|c|c|c|c|c|c|c|c|c|c|c|}
\hline & \multicolumn{2}{|c|}{ WACC 1} & \multicolumn{2}{|c|}{ WACC 2} & \multicolumn{2}{|c|}{ COD 1} & \multicolumn{2}{|c|}{ COD2 } & \multicolumn{2}{|c|}{$\mathrm{COE}$} \\
\hline & (1) & (2) & (1) & (2) & (1) & (2) & (1) & (2) & (1) & (2) \\
\hline \multicolumn{11}{|c|}{ Panel A. Low Current Ratio (Financially Constrained) } \\
\hline \multirow[t]{2}{*}{ Jumlah Segmen } & $0,02 * * *$ & & $0,01 * * *$ & & $(0,02) * * *$ & & $(0,02)^{* * *}$ & & $0,03 * * *$ & \\
\hline & 4,02 & & 3,27 & & 5,31 & & 5,65 & & 5,53 & \\
\hline \multirow{2}{*}{ Indeks Herfindahl } & & $0,09 * *$ & & $0,08 *$ & & 0,07 & & $0,12 * *$ & & 0,05 \\
\hline & & 2,03 & & 1,95 & & 1,18 & & 2,03 & & 1,18 \\
\hline \multirow[t]{2}{*}{ Leverage } & $(0,08)^{* * *}$ & $(0,09) * * *$ & $(0,08)^{* * *}$ & $(0,1)^{* * *}$ & $-0,02$ & $-0,01$ & $-0,03$ & $(0,04)^{*}$ & $0,05^{* *}$ & 0,01 \\
\hline & 3,87 & 4,45 & 4,54 & 5,04 & 0,73 & 0,27 & 1,31 & 1,77 & 2,29 & 0,52 \\
\hline \multirow[t]{2}{*}{ Return on Assets } & $-0,02$ & $(0,05)^{*}$ & $-0,02$ & $(0,05) * *$ & $(0,09) * *$ & $-0,3$ & $(0,07)^{*}$ & $-0,02$ & $0,05 * * *$ & 0,01 \\
\hline & 0,95 & 1,93 & 1,04 & 2,07 & 2,05 & 0,75 & 1,7 & 0,59 & 2,97 & 0,44 \\
\hline \multirow[t]{2}{*}{ Total Aset (Ln) } & $0,02 * * *$ & $0,02 * * *$ & $0,01 * * *$ & $0,02 * * *$ & $(0,01)^{*}$ & $-0,01$ & $(0,02)^{* * *}$ & $-0,01$ & $0,02 * * *$ & $0,02 * *$ \\
\hline & 2,86 & 3,07 & 2,84 & 2,91 & 1,94 & 0,5 & 3,38 & 0,42 & 3,48 & 2,11 \\
\hline \multirow[t]{2}{*}{ Market to book } & $(0,01)^{*}$ & $-0,01$ & $-0,01$ & $-0,01$ & $0,01 * * *$ & $0,01 * * *$ & $0,01 * * *$ & $0,01 * * *$ & $(0,01)^{* * *}$ & $-0,01$ \\
\hline & 1,75 & 1,49 & 1,44 & 1,34 & 3,08 & 3,82 & 2,87 & 2,75 & 2,83 & 1,15 \\
\hline \multirow[t]{2}{*}{$\mathrm{C}$} & $(0,4)^{* *}$ & $(0,48)^{* *}$ & $(0,34)^{* *}$ & $(0,39)^{* *}$ & $0,62 * * *$ & 0,24 & $0,9 * * *$ & 0,18 & $(0,69)^{* * *}$ & $(0,44)^{*}$ \\
\hline & 2,4 & 2,36 & 2,2 & 2,12 & 2,85 & 0,71 & 4,28 & 0,63 & 3,47 & 1,66 \\
\hline $\mathrm{N}$ & 105 & 105 & 105 & 105 & 105 & 105 & 105 & 105 & 105 & 105 \\
\hline Obser. fixed effec & YES & YES & YES & YES & YES & YES & YES & YES & YES & YES \\
\hline Adjusted R2 & 0,8 & 0,82 & 0,85 & 0,87 & 0,8 & 0,76 & 0,77 & 0,75 & 0,73 & 0,71 \\
\hline \multicolumn{11}{|c|}{ Panel B. High Current Ratio (Unfinancially Constrained) } \\
\hline \multirow[t]{2}{*}{ Jumlah Segmen } & 0,01 & & 0,01 & & $-0,01$ & & $-0,01$ & & $0,01 * * *$ & \\
\hline & 1,64 & & 1,43 & & 0,21 & & 0,07 & & 3,74 & \\
\hline \multirow[t]{2}{*}{ Indeks Herfindahl } & & $0,03 *$ & & $0,03 *$ & & $(0,09)^{* *}$ & & $-0,05$ & & 0,03 \\
\hline & & 1,86 & & 1,83 & & 2,09 & & 1,35 & & 1,62 \\
\hline \multirow{2}{*}{ Leverage } & $(0,06)^{* * *}$ & $(0,07)^{* * *}$ & $(0,06)^{* * *}$ & $(0,07)^{* * *}$ & $(0,08)^{*}$ & $(0,08)^{*}$ & $-0,06$ & $-0,06$ & $0,03^{*}$ & 0,03 \\
\hline & 3,51 & 4,01 & 3,36 & 3,87 & 1,78 & 1,78 & 1,63 & 1,54 & 1,83 & 1,75 \\
\hline \multirow[t]{2}{*}{ Return on Assets } & $-0,01$ & 0,02 & $-0,01$ & 0,01 & 0,13 & 0,12 & 0,06 & 0,05 & $-0,01$ & 0,01 \\
\hline & 0,01 & 0,85 & 0,27 & 0,53 & 1,88 & 1,74 & 1,13 & 0,92 & 0,6 & 0,48 \\
\hline \multirow[t]{2}{*}{ Total Aset (Ln) } & $0,02 * * *$ & $0,02 * * *$ & $0,02 * * *$ & $0,02 * * *$ & $-0,01$ & $-0,01$ & $-0,01$ & $-0,01$ & $0,04 * * *$ & $0,04 * * *$ \\
\hline & 4,71 & 4,92 & 4,55 & 4,9 & 0,42 & 0,64 & 0,93 & 1,01 & 8,01 & 7,11 \\
\hline \multirow[t]{2}{*}{ Market to book } & $0,01^{*}$ & $0,01 *$ & $0,01 *$ & $0,01 * *$ & $-0,01$ & $-0,01$ & $-0,01$ & $-0,01$ & $0,01 * * *$ & $0,01 * * *$ \\
\hline & 1,79 & 1,9 & 1,88 & 2,04 & 0,55 & 0,6 & 0,67 & 0,66 & 3 & 2,93 \\
\hline \multirow[t]{2}{*}{ C } & $(0,53)^{* * *}$ & $(0,53)^{* * *}$ & $(0,51)^{* * *}$ & $(0,51)^{* * *}$ & 0,25 & 0,37 & 0,35 & 0,39 & $(1,23)^{* * *}$ & $(1,09) * * *$ \\
\hline & 3,75 & 3,98 & 3,6 & 3,94 & 0,74 & 1,09 & 1,3 & 1,49 & 7,32 & 6,44 \\
\hline $\mathrm{N}$ & 120 & 120 & 120 & 120 & 120 & 120 & 120 & 120 & 120 & 120 \\
\hline Obser. fixed effec & YES & YES & YES & YES & YES & YES & YES & YES & YES & YES \\
\hline Adjusted R2 & 0,85 & 0,84 & 0,84 & 0,83 & 0,49 & 0,5 & 0,52 & 0,52 & 0,87 & 0,84 \\
\hline
\end{tabular}

$* * *, * *, *$ berturut-turut signifikan pada $1 \%, 5 \%$, dan $10 \%$

Nilai $t$-statistic disajikan dalam kurung

\section{Hasil Pengujian Simultan}

Setelah dilakukan pengujian secara bertahap untuk masing-masing variabel, kemudian dilakukan pengujian model secara keseluruhan untuk mengetahui seberapa konsisten hasil penelitian tersebut. Hasil pengujian secara simultan yang dipaparkan pada tabel 7 tidak jauh berbeda dengan pengujian sebelumnya. Diversifikasi usaha berpengaruh positif terhadap biaya modal dan biaya ekuitas, dan berpengaruh negatif terhadap biaya utang. Walaupun hipotesis penelitian pertama tidak terdukung, namun jika dilihat mekanisme pengaruhnya pada pengujian terpisah, hasilnya menunjukkan adanya konsistensi dengan kerangka pikir dari model penelitian yang dibangun. Akan tetapi, karena pengaruh positif diversifikasi usaha terhadap biaya ekuitas jauh lebih kuat dibanding pengaruh negatif diversifikasi usaha terhadap biaya utang, maka secara rata-rata biaya modal perusahaan justru semakin meningkat. 
Tabel 7. Hasil Pengujian Secara Simultan Pengaruh Diversifikasi Usaha, Korelasi Arus Kas, dan Kendala Pendanaan terhadap Biaya Modal

\begin{tabular}{|c|c|c|c|c|c|c|c|c|c|c|}
\hline & \multicolumn{2}{|c|}{ WACC 1} & \multicolumn{2}{|c|}{ WACC 2} & \multicolumn{2}{|c|}{ COD 1} & \multicolumn{2}{|c|}{ COD2 } & \multicolumn{2}{|c|}{$\mathrm{COE}$} \\
\hline & (1) & (2) & (1) & (2) & (1) & (2) & (1) & $(2)$ & (1) & (2) \\
\hline Jumlah Segmen & $\begin{array}{l}0,01 \\
(0,22)\end{array}$ & & $\begin{array}{l}0,01 \\
(0,07)\end{array}$ & & $\begin{array}{l}-0,05^{*} \\
(1,83)\end{array}$ & & $\begin{array}{l}-0,05^{* *} \\
(2,16)\end{array}$ & & $\begin{array}{l}0,01 \\
(0,54)\end{array}$ & \\
\hline Indeks Herfindahl & & $\begin{array}{l}0,13^{* *} \\
(2,1)\end{array}$ & & $\begin{array}{l}0,13 * * \\
(2,07)\end{array}$ & & $\begin{array}{l}-0,26 * * * \\
(2,87)\end{array}$ & & $\begin{array}{l}-0,21 * * * \\
(2,92)\end{array}$ & & $\begin{array}{l}2,23 * * * \\
(3,26)\end{array}$ \\
\hline Kor. arus kas (CFC) & $\begin{array}{l}0,03 \\
(0,61)\end{array}$ & $\begin{array}{l}0,1 * * * \\
(2,72)\end{array}$ & $\begin{array}{l}0,02 \\
(0,41)\end{array}$ & $\begin{array}{l}0,1 * * * \\
(2,78)\end{array}$ & $\begin{array}{l}-0,1 \\
(0,87)\end{array}$ & $\begin{array}{l}-0,06 \\
(1,56)\end{array}$ & $\begin{array}{l}-0,12 \\
(1,33)\end{array}$ & $\begin{array}{l}-0,06^{*} \\
(1,88)\end{array}$ & $\begin{array}{l}0,03 \\
(0,44)\end{array}$ & $\begin{array}{l}0,16^{* * *} \\
(3,77)\end{array}$ \\
\hline Kendala Pendanaan & $\begin{array}{l}-0,02^{* *} \\
(2,5)\end{array}$ & $\begin{array}{l}-0,02 * * \\
(2,02)\end{array}$ & $\begin{array}{l}-0,02 * * \\
(2,12)\end{array}$ & $\begin{array}{l}-0,01 * \\
(1,83)\end{array}$ & $\begin{array}{l}-0,01 \\
(0,51)\end{array}$ & $\begin{array}{l}0,03 * * * \\
(3,19)\end{array}$ & $\begin{array}{l}-0,01 \\
(0,05)\end{array}$ & $\begin{array}{l}0,03 * * * \\
(3,51)\end{array}$ & $\begin{array}{l}-0,03 * \\
(1,9)\end{array}$ & $\begin{array}{l}-0,03 * * * \\
(2,95)\end{array}$ \\
\hline $\mathrm{JS} * \mathrm{CFC}$ & $\begin{array}{l}-0,01 \\
(0,07)\end{array}$ & & $\begin{array}{l}-0,01 \\
(0,19)\end{array}$ & & $\begin{array}{l}0,04 \\
(1,22)\end{array}$ & & $\begin{array}{l}0,05^{*} \\
(1,83)\end{array}$ & & $\begin{array}{l}-0,01 \\
(0,72)\end{array}$ & \\
\hline JS*DPR & $\begin{array}{l}0,01 * \\
(1,75)\end{array}$ & & $\begin{array}{l}0,01 * \\
(1,76)\end{array}$ & & $\begin{array}{l}-0,01 \\
(0,87)\end{array}$ & & $\begin{array}{l}-0,01 \\
(0,4)\end{array}$ & & $\begin{array}{l}0,01 \\
(1,62)\end{array}$ & \\
\hline $\mathrm{IH} * \mathrm{CFC}$ & & $\begin{array}{l}-0,17 * * \\
(2,41)\end{array}$ & & $\begin{array}{l}-0,16 * * \\
(2,27)\end{array}$ & & $\begin{array}{l}0,24 * * \\
(2,51)\end{array}$ & & $\begin{array}{l}0,25^{* * *} \\
(3,12)\end{array}$ & & $\begin{array}{l}-0,3 * * * \\
(3,56)\end{array}$ \\
\hline $\mathrm{IH} * \mathrm{DPR}$ & & $\begin{array}{l}0,03 * * \\
(2,09)\end{array}$ & & $\begin{array}{l}0,03 * \\
(1,87)\end{array}$ & & $\begin{array}{l}-0,05^{* *} \\
(2,26)\end{array}$ & & $\begin{array}{l}-0,04^{* *} \\
(2,28)\end{array}$ & & $\begin{array}{l}0,06 * * * \\
(2,76)\end{array}$ \\
\hline Leverage & $\begin{array}{l}-0,07 * * * \\
(5,21)\end{array}$ & $\begin{array}{l}-0,07 * * * \\
(5,5)\end{array}$ & $\begin{array}{l}-0,08 * * * \\
(5,47)\end{array}$ & $\begin{array}{l}-0,08 * * * \\
(5,74)\end{array}$ & $\begin{array}{l}-0,06 * * * \\
(2,7)\end{array}$ & $\begin{array}{l}-0,06 * * * \\
(2,76)\end{array}$ & $\begin{array}{l}-0,07 * * * \\
(3,51)\end{array}$ & $\begin{array}{l}-0,09 * * * \\
(4,84)\end{array}$ & $\begin{array}{l}-0,03 * * \\
(2,04)\end{array}$ & $\begin{array}{l}-0,03 * \\
(1,86)\end{array}$ \\
\hline Return on Assets & $\begin{array}{l}-0,03 \\
(1,42)\end{array}$ & $\begin{array}{l}-0,03 \\
(1,53)\end{array}$ & $\begin{array}{l}-0,03 \\
(1,36)\end{array}$ & $\begin{array}{l}-0,03 \\
(1,65)\end{array}$ & $\begin{array}{l}-0,03 \\
(1,12)\end{array}$ & $\begin{array}{l}0,03 \\
(1,13)\end{array}$ & $\begin{array}{l}-0,04 \\
(1,43)\end{array}$ & $\begin{array}{l}-0,04 \\
(1,48)\end{array}$ & $\begin{array}{l}0,03 \\
(1,64)\end{array}$ & $\begin{array}{l}0,03 \\
(1,37)\end{array}$ \\
\hline Total Aset (Ln) & $\begin{array}{l}0,02 * * * \\
(3,71)\end{array}$ & $\begin{array}{l}0,01 * * * \\
(3,94)\end{array}$ & $\begin{array}{l}0,01 * * * \\
(3,25)\end{array}$ & $\begin{array}{l}0,01 * * * \\
(3,81)\end{array}$ & $\begin{array}{l}-0,01 * * \\
(2,2)\end{array}$ & $\begin{array}{l}-0,01 * * \\
(2,11)\end{array}$ & $\begin{array}{l}-0,02 * * * \\
(2,7)\end{array}$ & $\begin{array}{l}-0,02 * * * \\
(2,7)\end{array}$ & $\begin{array}{l}0,03 * * * \\
(4,88)\end{array}$ & $\begin{array}{l}0,02 * * * \\
(4,61)\end{array}$ \\
\hline Book to Market & $\begin{array}{l}-0,01 \\
(0,75)\end{array}$ & $\begin{array}{l}-0,01 \\
(0,62)\end{array}$ & $\begin{array}{l}-0,01 \\
(0,53)\end{array}$ & $\begin{array}{l}-0,01 \\
(0,27)\end{array}$ & $\begin{array}{l}0,03 * * \\
(2,25)\end{array}$ & $\begin{array}{l}0,04 * * * \\
(2,92)\end{array}$ & $\begin{array}{l}0,03 * * \\
(2,17)\end{array}$ & $\begin{array}{l}0,04^{* * *} \\
(2,88)\end{array}$ & $\begin{array}{l}-0,01 \\
(0,91)\end{array}$ & $\begin{array}{l}-0,01 \\
(0,47)\end{array}$ \\
\hline $\mathrm{C}$ & $\begin{array}{l}-0,37 * * * \\
(2,67)\end{array}$ & $\begin{array}{l}-0,36^{* * *} \\
(3,22)\end{array}$ & $\begin{array}{l}-0,28^{* *} \\
(2,15)\end{array}$ & $\begin{array}{l}-0,35^{* * *} \\
(3,13)\end{array}$ & $\begin{array}{l}0,7 * * * \\
(2,91)\end{array}$ & $\begin{array}{l}0,62 * * * \\
(2,9)\end{array}$ & $\begin{array}{l}0,03 * * \\
(2,17)\end{array}$ & $\begin{array}{l}0,64 \text { *** } \\
(3,53)\end{array}$ & $\begin{array}{l}-0,66^{* * *} \\
(3,86)\end{array}$ & $\begin{array}{l}-0,71 * * * \\
(4,58)\end{array}$ \\
\hline $\mathrm{N}$ & 225 & 225 & 225 & 225 & 225 & 225 & 225 & 225 & 225 & 225 \\
\hline Obser. fixed effect & YES & YES & YES & YES & YES & YES & YES & YES & YES & YES \\
\hline Adjusted R2 & 0,796 & 0,847 & 0,813 & 0,86 & 0,735 & 0,79 & 0,723 & 0,801 & 0,76 & 0,789 \\
\hline
\end{tabular}

$* * *, * *, *$ berturut-turut signifikan pada $1 \%, 5 \%$, dan $10 \%$

Nilai $t$-statistic disajikan dalam kurung

\section{Simpulan dan Saran Pengembangan}

Hasil penelitian menunjukkan diversifikasi usaha berpengaruh negatif terhadap biaya utang. Semakin tinggi tingkat diversifikasi, semakin rendah risiko kebangkrutan, sehingga biaya utang juga semakin rendah. Di sisi lain, ketika terjadi peningkatan leverage akibat penurunan risiko kebangkrutan, biaya ekuitas akan meningkat. Penelitian ini menunjukkan peningkatan biaya ekuitas lebih kuat dibanding penurunan biaya utang, sehingga secara rata-rata biaya modal perusahaan justru meningkat.

Temuan lain menunjukkan korelasi arus kas antar segmen secara signifikan memperlemah pengaruh diversifikasi usaha terhadap biaya modal. Perusahaan terdiversifikasi dengan korelasi arus kas yang rendah memiliki biaya modal rata-rata lebih rendah dibanding perusahaan terdiversifikasi dengan korelasi arus kas yang tinggi. Variabel kendala pendanaan juga menunjukkan pengaruh signifikan dalam memperkuat pengaruh diversifikasi usaha terhadap biaya modal. Semakin tinggi kendala pendanaan yang dihadapi, semakin besar manfaat diversifikasi usaha bagi perusahaan.

Hasil penelitian yang menunjukkan diversifikasi usaha justru berpengaruh positif terhadap biaya modal bisa jadi dipengaruhi oleh tipe diversifikasi yang dilakukan perusahaan. Sebagian besar perusahaan sampel menerapkan strategi diversifikasi terkait yang ditunjukkan oleh tingginya tingkat korelasi arus kas antar unit bisnis perusahaan. Temuan ini semakin memperkuat temuan sebelumnya yang dilakukan oleh Duchin (2010), Kuppuswamy dan Villalonga (2010), serta Rajan et. al. (2000) 
yang menunjukkan semakin tinggi tingkat keterkaitan usaha, semakin kecil manfaat co-insurance yang dihasilkan. Hal ini kemudian diperkuat dengan tingkat utang perusahaan yang secara rata-rata juga masih rendah.

Adapun berbagai keterbatasan penelitian ini yang sekaligus menjadi saran untuk penelitian selanjutnya, yaitu:

a. Fokus penelitian ini hanya pada perusahaan terdiversifikasi sehingga tidak bisa dijelaskan besaran tambahan manfaat yang didapat atau biaya yang ditanggung perusahaan terdiversifikasi dibanding perusahaan tidak terdiversifikasi dalam konteks biaya modal. Penelitian selanjutnya diharapkan bisa melihat perbedaan pengaruh tersebut secara lebih jelas dengan membandingkan biaya modal kedua jenis perusahaan tersebut.

b. Penelitian ini menggunakan realized returns dalam menghitung expected returns. Sudah banyak literatur yang menyebutkan metode ini dapat memberikan hasil yang bias, karena terkontaminasi dengan information shocks yang terjadi di pasar (Elton, 1999). Alternatif metode lain sebenarnya sudah banyak berkembang, seperti implied cost of equity yang dikembangkan oleh Claus dan Thomas (2001), Easton (2004), Gebhardt, Lee, dan Swaminathan (2001). Untuk bisa menerapkan metode ini diperlukan data dari analyst forecasts yang jumlahnya masih sangat terbatas di Indonesia. Berdasarkan data yang diterima dari Bloomberg, perusahaan yang memiliki data analyst forecasts sebagian besar berasal dari sektor perbankan, sedangkan untuk yang non-bank, secara umum hanya diperuntukkan bagi perusahaan dengan nilai kapitalisasi pasar yang besar. Penelitian selanjutnya diharapkan dapat memperbaiki kelemahan ini.

c. Dengan keterbatasan data, penelitian ini hanya menggunakan definisi arus kas yang masih sangat tradisional yaitu EBITDA (earnings before interest, taxes, depreciation, and amortization). Penelitian selanjutnya diharapkan dapat menghitung korelasi arus kas antar segmen secara lebih komprehensif.

d. Metode klasifikasi perusahaan yang mengalami financially constrained dan unfinancially constrained dilakukan dengan menggunakan nilai median sebagai cut-off. Salah satu keterbatasan dari metode ini adalah hasil estimasi sangat bergantung pada sampel penelitian. Penelitian selanjutnya diharapkan dapat melakukan metode klasifikasi yang lebih baik sehingga lebih mampu menggambarkan kondisi perusahaan yang sebenarnya.

\section{Daftar Pustaka}

Amihud, Y., \& Lev B. (1981). Risk reduction as a managerial motive for conglomerate mergers. Bell Journal of Economics, 12(2), 605-6017.

Barton. S. \& Gordon, P. (1988). Corporate strategy and capital structure. StrategicManagement Journal, $9(6)$, 623-632.

Berger, P. G., \& Ofek, E. (1995). Diversification's effect on firm value. Journal of Financial Economics, 37(1), 39-65.

Bodie, Z., Kane A., \& Marcus, A. J. (2011). Investmentsand portfolio management. Global Edition. McGraw-Hill. Singapore.

Campa, J. M., \& Kedia S. (2002). Explaining the diversification discount. Journal of Finance, 57(4), $1731-1762$.

Claus, J. J., \& Thomas J. K. (2001). Equity premia as low as three percent? Evidence from analysts' earnings forecasts for domestic and international stocks markets. Journal of Finance, 56(5), 1629-1666.

Denis, D. J., Denis D. K., \& Sarin A. (1997). Agency problems, equity ownership, and corporate diversification. Journal of Finance, 52(1), 135-160.

Duchin, R. (2010). Cash holdings and corporate diversification. Journal of Finance, 65(3), 955-992. 
Easton P. D. (2004). PE ratios, PEG ratios, and estimating the implied expected rate of return on equity capital. The Accounting Review, 79(1), 73-96.

Ehrhardt, M. C., \& Brigham E. F. (2011). Financial management: Theory and practice. $13^{\text {th }}$ Edition. South-Western Cengage Learning. USA.

Elton E. J. (1999). Expected return, realized return, and asset pricing tests. Journal of Finance, 54(4), 1199-1220.

Franco, F., Urcan O., \& Vasvari F. P. (2010). The value of corporate diversification: A debt market perspective. Working Paper.

Galai, D., \&Masulis R. W. (1976). The option pricing model and the risk factor of stock. Journal of Financial Economics, 3(1), 53-81.

Gebhardt, W. R., Lee C. M. C., \& Swaminathan B. (2001). Towards an ex-antecost of capital.Journal of Accounting Research, 39(1), 135-176.

Graham, J. R., Lemmon M., \& Wolf J. (2002). Does corporate diversification destroy value?.Journal of Finance, 57(2), 695-720.

Gujarati, D. N., \& Porter D. C. (2011). Basic Econometrics. Fifth Edition. Mc. Grawhill. Singapore.

Hann, R. N., Ogneva M., \& Ozbas O. (2013). Corporate diversification and the cost of capital. Journal of Finance, 68(5), 1961-1999.

Higgins, R. C., \& Schall L. D. (1975). Corporate bankruptcy and conglomerate merger. Journal of Finance,30(1), 93-113.

Hoshi, T., Kashyap A., \& David Scharfstein. (1991). Corporate structure, liquidity, and investment: Evidence from Japanese industrial groups. Quarterly Journal of Economics, 106(1), 33-60.

Hyland, D.C. \&DiltzJ. D.(2002). Why firms diversify: An empirical examination. Financial Management, 31(1), 51-81.

Jahera, J. S., \& Lloyd W. P. (1996). An empirical assessment of factors affecting corporate debt levels. Managerial Finance, 22(2), 29-38.

Jensen, M. C. (1986). Agency costs of free cash flow, corporate finance, and takeovers. American Economic Review, 76(2), 323-330.

Jensen, M., \& Meckling W. (1976). The theory of the firm: Managerial behavior, agency costs, and ownership structure. Journal of Financial Economics, 3(4), 305-360.

Kim, E. H., \& McConnell J. J. (1977). Corporate mergers and the co-insurance of corporate debt. Journal of Finance,32(2), 349-365.

Kini, O., \& Williams R. (2012). Tournament incentives, firm risk, and corporate policies. Journal of Financial Economics, 103(2), 350-376.

Kraus, A., \& Litzenberger R.H. (1973). A state-preference model of optimal financialleverage. Journal of Finance,28(4), 911-922.

Kuppuswamy, V.,\& Villalonga B. (2010). Does diversification create value in the presence of external financing constraints? Evidence from the 2007-2009 financial crisis. Working Paper, Harvard Business School.

Lang, L.H.P., \& Stulz R.E. (1994). Tobin's Q, corporate diversification, and firm performance.Journal of Political Economy, 102(6), 1248-1281. 
Leland, H. E. (2007). Financial synergies and the optimal scope of the firm: Implications for mergers, spinoffs, and structured finance. Journal of Finance, 62(2), 765-807.

Lewellen, W. G. (1971). A pure financial rationale for the conglomerate merger. Journal of Finance, 26(2), 527-537.

Mansi, S., \& Reeb D. (2002). Corporate diversification: What gets discounted?. Journal of Finance, 57(5), 2167-2183.

Matsusaka, J. G., \& Nanda V. (2002). Internal capital markets and corporate refocusing. Journal of Financial Intermediation, 11(2), 176-211.

May, D. O. (1995). Do managerial motives influence firm risk reduction strategies?. Journal of Finance, 50(4), 1291-1308.

Meyer, M., Milgrom P.,\& Roberts J. (1992). Organizational prospects, influence costs, and ownership changes. Journal of Economics and Management Strategy, 1(1), 9-35.

Oweis, A. (2012). The impact of corporate diversification on the financial performance of US bank holding companies pre and post the financial service modernization act of 1999. Dissertation of Claremont Graduate University.

Rajan, R., Servaes H., \& Zingales L. (2000). The cost of diversity: The diversification discount and inefficient investment. Journal of Finance, 55(1), 35-80.

Ross, S. A., Westerfield R.W., \& Jaffe J. (2008). Corporate Finance. 8th edition. McGraw-Hill, New York.

Schall, L. D. (1972). Asset valuation, firm investment, and firm diversification. Journal of Business, 45(1), 11-28.

Scharfstein, D. (1999). The dark side of internal capital markets II: Evidence from diversified conglomerates. Working paper 6352, NBER.

Schoar, A. (2002). Effects of corporate diversification on productivity. Journal of Finance, 57(6), 2379-2403.

Scott J. H. (1977). On the theory of conglomerate mergers. Journal of Finance, 32(4), 1235-1250.

Shleifer, A., \& Vishny R. W.(1992). Liquidation values and debt capacity: A market equilibrium approach. Journal of Finance, 47(4), 1343-1366.

Stein, J. (1997). Internal capital market and the competition for corporate resources. Journal of Finance, 52(1), 111-133.

Stulz, R. (1990). Managerial discretion and optimal financing policies. Journal of Financial Economics, 26(1), 3-27.

Villalonga, B. (2004). Does diversification cause the "diversification discount"?.Financial Management, 33(2), 5-23.

Wernerfelt, B., \& Montgomery C. (1988). Diversification, ricardian rents, and tobin's q. Journal of Economics, 19(4), 246-250.

Yan, A. (2006). Value of conglomerates and capital market conditions. Financial Management, 35(4), 5-30. 